NBER WORKING PAPER SERIES

\title{
DEBT INTOLERANCE
}

\author{
Carmen M. Reinhart \\ Kenneth S. Rogoff \\ Miguel A. Savastano \\ Working Paper 9908 \\ http://www.nber.org/papers/w9908
}

\section{NATIONAL BUREAU OF ECONOMIC RESEARCH 1050 Massachusetts Avenue Cambridge, MA 02138}

August 2003

Paper prepared for the Brookings Panel on Economic Activity Conference of March 27-28, 2003. Copyright 2003, Brookings Institution; reproduced with permission of the Brookings Papers on Economic Activity. The opinions expressed in this paper are those of the authors and do not necessarily represent the views of the International Monetary Fund. The authors would like to thank Morris Goldstein, Harold James, Jens Nystedt, Vincent Reinhart, Christopher Sims, and John Williamson for useful comments and suggestions, and Mike Treadway for editorial help. Ethan Ilzetzki, Kenichiro Kashiwase, and Yutong Li provided excellent research assistance. The views expressed herein are those of the authors and not necessarily those of the National Bureau of Economic Research.

(C2003 by Carmen M. Reinhart, Kenneth S. Rogoff, and Miguel A. Savastano. All rights reserved. Short sections of text, not to exceed two paragraphs, may be quoted without explicit permission provided that full credit, including (C) notice, is given to the source. 
Debt Intolerance

Carmen M. Reinhart, Kenneth S. Rogoff, and Miguel A. Savastano

NBER Working Paper No. 9908

August 2003

JEL No. F3, F31, F34

\begin{abstract}
This paper introduces the concept of "debt intolerance," which manifests itself in the extreme duress many emerging markets experience at debt levels that would seem manageable by advanced country standards. We argue that "safe" external debt-to-GNP thresholds for debt intolerant countries are low, perhaps as low as 15 percent in some cases. These thresholds depend on a country's default and inflation history. Debt intolerance is linked to the phenomenon of serial default that has plagued many countries over the past two centuries. Understanding and measuring debt intolerance is fundamental to assess the problems of debt sustainability, debt restructuring, capital market integration, and the scope for international lending to ameliorate crises. Our goal is to make a first pass at quantifying debt intolerance, including delineating debtors' clubs and regions of vulnerability, on the basis on a history of credit events going back to the 1820 s for over 100 countries.
\end{abstract}

$\begin{array}{lll}\text { Carmen M. Reinhart } & \text { Kenneth S. Rogoff } & \text { Miguel A. Savastano } \\ \text { Research Department } & \text { Research Department } & \text { Research Department } \\ \text { International Monetary Fund } & \text { International Monetary Fund } & \text { International Monetary Fund } \\ 70019^{\text {th }} \text { Street, NW } & 70019^{\text {th }} \text { Street, NW } & 70019^{\text {th }} \text { Street, NW } \\ \text { Washington, DC 20431 } & \text { Washington, DC 20431 } & \text { Washington, DC 20431 } \\ \text { and NBER } & \text { and NBER } & \text { msavastano@imf.org } \\ \text { creinhar@umd.edu } & \text { krogoff@imf.org } & \end{array}$




\section{INTRODUCTION}

In this paper we argue that history matters: that a country's record at meeting its debt obligations and managing its macroeconomy in the past is relevant to forecasting its ability to sustain moderate to high levels of indebtedness, both domestic and external, for many years into the future. We introduce the concept of debt intolerance (drawing an analogy to, for example, "lactose intolerance"), which manifests itself in the extreme duress many emerging market economies experience at overall debt levels that would seem quite manageable by the standards of the advanced industrial economies. For external debt, "safe" thresholds for highly debtintolerant emerging markets appear to be surprisingly low, perhaps as low as 15 to 20 percent of GNP in many cases, and these thresholds depend heavily on the country's record of default and inflation. Debt intolerance is indeed intimately linked to the pervasive phenomenon of serial default that has plagued so many countries over the past two centuries. Debt-intolerant countries tend to have weak fiscal structures and weak financial systems. Default often exacerbates these problems, making these same countries more prone to future default. Understanding and measuring debt intolerance is fundamental to assessing the problems of debt sustainability, debt restructuring, capital market integration, and to assessing the scope for international lending to ameliorate crises.

Certainly, the idea that factors such as sound institutions and a history of good economic management affect the interest rate at which a country can borrow is well developed in the theoretical literature. Also well established is the notion that, as its external debt rises, a country becomes more vulnerable to being suddenly shut out of international capital markets, 
that is, to suffer a debt crisis. ${ }^{1}$ However, there has to date been no attempt to make these abstract theories operational by identifying the factors (in particular, a history of serial default or restructuring) that govern how quickly a country becomes vulnerable to a debt crisis as its external obligations accumulate. One goal of this paper is to quantify this debt intolerance, drawing on a history of adverse credit events going back to the $1820 \mathrm{~s}$. We argue that a country's current level of debt intolerance can be approximated empirically as the ratio of the long-term average of its external debt (scaled by GNP or exports) to an index of default risk. We recognize that other factors, such as the degree of dollarization, indexation to inflation or short-term interest rates, and the maturity structure of a country's debt, are also relevant to assessing a country's vulnerability to symptoms of debt intolerance. ${ }^{2}$ We argue, however, that in general these factors are different manifestations of the same underlying institutional weaknesses. Indeed, unless these weaknesses are addressed, the notion that the "original sin" of serial defaulters can be extinguished through some stroke of financial engineering, allowing these countries to borrow in the same amounts, relative to GNP, as more advanced economies, much less at the same interest rates, is sheer folly. ${ }^{3}$

The first section of the paper gives a brief overview of the history of serial default on external debt, showing that it is a remarkably pervasive and enduring phenomenon: the European countries set benchmarks, centuries ago, that today's emerging markets have yet to

\footnotetext{
${ }^{1}$ See Obstfeld and Rogoff (1996, chapter 6).

${ }^{2}$ See Goldstein (2003) for a comprehensive discussion of these factors.

${ }^{3}$ Some analysts, such as Eichengreen, Hausmann, and Panizza (2002), have put the blame for recurring debt cycles on the incompleteness of international capital markets and have proposed mechanisms to make it easier for emerging market economies to borrow more. Needless to say, our view is that the main problem for these countries is how to borrow less. For another critical discussion of the notion of original sin, argued on different grounds, see Reinhart and Reinhart (2003).
} 
surpass. For example, Spain defaulted on its external debt thirteen times between 1500 and 1900, whereas Venezuela, the record holder in our sample for the period since 1824, has defaulted "only" nine times. We go on to show how countries can be divided into debtors' "clubs" and, within those clubs, more or less debt-intolerant "regions," depending on their credit and inflation history. We also develop first broad-brush measures of safe debt thresholds. The data overwhelmingly suggest that the thresholds for emerging market economies with high debt intolerance are much lower than those for advanced industrial economies or for those emerging market economies that have never defaulted on their external debt. Indeed, fully half of all defaults or restructurings since 1970 took place in countries with ratios of external debt to GNP below 60 percent. $^{4}$

Our key finding, presented in the second section of the paper, is that a country's external debt intolerance can be explained by a very small number of variables related to its repayment history, indebtedness level, and history of macroeconomic stability. Markets view highly debtintolerant countries as having an elevated risk of default, even at relatively low ratios of debt to output or exports. Whether markets adequately price this risk is an open question, but it is certainly a risk that the citizens of debt-intolerant countries should be aware of when their leaders engage in heavy borrowing.

The third section turns to the question of how debt intolerance affects conventional calculations of debt sustainability, which typically assume continual market access. For debt-

\footnotetext{
${ }^{4}$ See Sims (2001) for a model that implies that an economy with low taxation and low indebtedness may optimally repudiate its debt, or inflate at high rates, more frequently than an economy that has inherited high levels of taxation and debt (as have some industrial economies). Indeed, as we shall see, and consistent with some of the predictions of that model, the countries with the highest historical default probabilities, and the highest probability of inflation rates above 40 percent a year, also had (on average) much lower levels of debt than the typical industrial economy.
} 
intolerant countries, sustaining access to capital markets can be problematic unless debt ratios are quickly brought down to safer levels. To assess how such "deleveraging" might be accomplished, we examine how, historically, emerging market economies with substantial external debts have managed to work them down. To our knowledge, this is a phenomenon that has previously received very little, if any, attention. We analyze episodes of large debt reversals, where countries' external debt fell by more than 25 percentage points of GNP over a three-year period. Of the twenty-two such reversals that we identify for a broad group of middle-income countries since 1970, almost two-thirds involved some form of default or restructuring. (Throughout this paper, "restructuring" denotes a recontracting of debt service payments at terms that are tantamount to partial default.) Only in one case- Swaziland in 1985 — was a country able to bring down a high ratio of external debt to GNP solely as a result of rapid output growth.

Because history plays such a large role in our analysis, we focus primarily on understanding emerging market economies' access to external capital markets. For most emerging markets, external borrowing has been the only financial game in town for much of the past two centuries, and our debt thresholds are calculated accordingly. Over the past decade or so, however, a number of emerging market economies have, for the first time, seen a rapid expansion in domestic, market-based debt, as we document using an extensive new data set, which we present in the paper's fourth section. The calculus of domestic default obviously differs from that of default on external debt, and we lack sufficient historical data to investigate this question fully. However, we argue that a record of external debt intolerance is likely to be a good predictor of future domestic debt intolerance. It is certainly the case that many of the major debt crises of the past ten years have involved domestic debt, and that the countries that 
seem to be experiencing "domestic debt intolerance" rank high on our debt intolerance measures. $^{5}$

Finally, if serial default is such a pervasive phenomenon, why do markets repeatedly lend to debt-intolerant countries to the point where the risk of a credit event - a default or a restructuring - becomes significant? Part of the reason may have to do with the procyclical nature of capital markets, which have repeatedly lent vast sums to emerging market economies in boom periods (which are often associated with low returns in the industrial countries) only to retrench when adverse shocks occur, producing painful "sudden stops." " As for the extent to which borrowing countries themselves are complicit in the problem, one can only conclude that, throughout history, governments have often been too short-sighted (or too corrupt) to internalize the significant risks that overborrowing produces over the longer term. Moreover, in the modern era, multilateral institutions have been too complacent (or have had too little leverage) when loans were pouring in. Thus a central conclusion of this paper is that, for debtintolerant countries, mechanisms to limit borrowing, either through institutional change on the

\footnotetext{
${ }^{5}$ Some policymakers, of course, have come to recognize the problem at least since the Mexican debt crisis of 1994. The academic literature has lagged behind, in part because of lack of data, but also because the theoretical connections between external and domestic debt have not been well articulated. Nonetheless, among the participants in this debate, Ronald McKinnon merits special mention for anticipating the emergence of domestic government debt as a problem to be reckoned with. McKinnon wrote in 1991 that "One of the most striking developments of the late 1980s was the extent to which the governments of Mexico, Argentina and Brazil went into debt domestically. Because of the cumulative effect of very high interest rates ... on their existing domestic liabilities, government-debt-to-GNP ratios have been building up in an unsustainable fashion even though most of these countries are not paying much on their debts to international banks. In many [developing countries], people now anticipate that governments will default on its own domestic bonds - as in March 1990 with the Brazilian government's freeze of its own outstanding liabilities" (McKinnon, 1991, p. 6).

${ }^{6}$ The procyclicality of capital flows to developing countries has been amply documented, particularly since Carlos Díaz-Alejandro called attention to the phenomenon on the eve of the Latin American debt crisis of the 1980s (Díaz-Alejandro, 1983, 1984). For a recent and systematic review of the evidence on the procyclicality of capital flows, see Kaminsky, Reinhart, and Végh (2003).
} 
debtor side, or - in the case of external borrowing - through changes in the legal or regulatory systems of creditor countries, are probably desirable. ${ }^{7}$

\section{DEBT INTOLERANCE: ORIGINS AND IMPLICATIONS FOR BORROWING}

We begin by sketching the history of debt intolerance and serial default, to show how this history importantly influences what "debtors' club" a country belongs to.

Debt Intolerance and Serial Default in Historical Perspective.

A bit of historical context will help to explain our approach, which draws on a country's long-term debt history. The basic point is that many countries that have defaulted on their external debts have done so repeatedly, with remarkable similarities across the cycles. For example, many of the Latin American countries that are experiencing severe debt problems today also experienced debt problems in the 1980s — and in the 1930s, and in the 1870s, and in the 1820 s, and generally at other times as well. Brazil, whose debt problems have attracted much attention lately, has defaulted seven times on its external debt over the past 175 years. During that same period, Venezuela has defaulted nine times, as noted at the outset, and Argentina four times, not counting its most recent episode. But the problem is by no means limited to Latin America. For example, Turkey, which has been a center of attention of late, has defaulted six times over the past 175 years. These same countries have at times also defaulted, de facto, on their internal obligations, including through high inflation or hyperinflation. On the other side of the ledger, a number of countries have strikingly averted

\footnotetext{
${ }^{7}$ The need for institutional and legal changes to help rechannel capital flows to developing countries from debt toward foreign direct investment, other forms of equity, and aid, so as to prevent the recurrence of debt crises, is the central theme of Bulow and Rogoff (1990).
} 
outright default, or restructuring that reduced the present value of their debt, over the decades and centuries. India, Korea, Malaysia, Singapore, and Thailand are members of this honor roll.

The contrast between the histories of the nondefaulters and those of the serial defaulters, summarized in table 1, is stunning. Default can become a way of life. Over the period from 1824 to 2001, the debts of Brazil and Argentina were either in default or undergoing restructuring a quarter of the time, those of Venezuela and Colombia almost 40 percent of the time, and that of Mexico for almost half of all the years since its independence. On average, the serial defaulters have had annual inflation exceeding 40 percent roughly a quarter of the time as well. ${ }^{8}$ By contrast, the emerging market economies in the table that have no external default history do not count a single twelve-month period with inflation over 40 percent among them. For future reference, the table also includes a sampling of advanced economies with no modern history of external default.

\footnotetext{
${ }^{8}$ The list of serial defaulters in table 1 is far from complete. Russia's 1998 default was hardly the first for that country (as table 2 shows, although the period covered does not include the default on the tsarist debt after the 1917 revolution ). Many other countries have also defaulted on their external debts, including, recently, Indonesia and Ukraine in 1998, Pakistan in 1999, and Ecuador in 2000.
} 
Table 1. Inflation, External Debt Defaults and Country Risk: 1824-2001

\begin{tabular}{ccccc}
\hline \hline Percent of 12- & Number of & Percent of & Number of years & Institutional \\
month periods & default or & years in a state & since last year in & Investor \\
with inflation at & restructuring & of default or & default or & Ratings, \\
or above 40 & episodes & restructuring & restructuring & September \\
percent, & $1824-1999$ & $1824-1999$ & status & $2002^{b}$ \\
$1958: 1-2001: 12^{a}$ & & & \\
\hline \hline
\end{tabular}

Emerging market countries with at least one external default or restructuring since 1824

\begin{tabular}{|c|c|c|c|c|c|}
\hline Argentina & 47.2 & 4 & 25.6 & 0 & 15.8 \\
\hline Brazil & 59.0 & 7 & 25.6 & 7 & 39.9 \\
\hline Chile & 18.6 & 3 & 23.3 & 17 & 66.1 \\
\hline Colombia & 0.8 & 7 & 38.6 & 57 & 38.7 \\
\hline Egypt & 0.0 & 2 & 12.5 & 17 & 45.5 \\
\hline Mexico & 16.7 & 8 & 46.9 & 12 & 59.0 \\
\hline Philippines & 2.1 & 1 & 18.5 & 10 & 44.9 \\
\hline Turkey & 57.8 & 6 & 16.5 & 20 & 33.8 \\
\hline Venezuela & 11.6 & 9 & 38.6 & 4 & 30.6 \\
\hline Group average & 23.8 & 5.2 & 27.3 & 16 & 41.6 \\
\hline \multicolumn{6}{|c|}{ Emerging market countries with no external default history } \\
\hline India & 0.0 & 0 & 0.0 & $\ldots$ & 47.3 \\
\hline Korea & 0.0 & 0 & 0.0 & $\ldots$ & 65.6 \\
\hline Malaysia & 0.0 & 0 & 0.0 & $\ldots$ & 57.7 \\
\hline Singapore & 0.0 & 0 & 0.0 & $\ldots$ & 86.1 \\
\hline Thailand & 0.0 & 0 & 0.0 & $\ldots$ & 51.9 \\
\hline Group average & 0.0 & 0 & 0.0 & $\ldots$ & 61.7 \\
\hline \multicolumn{6}{|c|}{ Industrial economies with no external default history } \\
\hline Australia & 0.0 & 0 & 0.0 & $\ldots$ & 84.5 \\
\hline Canada & 0.0 & 0 & 0.0 & $\ldots$ & 89.4 \\
\hline New Zealand & 0.0 & 0 & 0.0 & $\ldots$ & 81.2 \\
\hline Norway & 0.0 & 0 & 0.0 & $\ldots$ & 93.1 \\
\hline United & 0.0 & 0 & 0.0 & $\ldots$ & 94.1 \\
\hline \multicolumn{6}{|l|}{ Kingdom } \\
\hline United States & 0.0 & 0 & 0.0 & $\ldots$ & 93.1 \\
\hline Group average & 0.0 & 0 & 0.0 & $\ldots$ & 89.2 \\
\hline
\end{tabular}

\footnotetext{
${ }^{\text {a }}$ Period begins in: 1962:1 for Singapore; 1964:1 for Brazil; 1966:1 for Thailand; 1970:1 for Turkey; and 1971:1 for Korea.

b. On a scale from 0 to 100 , where 100 indicates the lowest probability of default on government debt. Notes: ... denotes not applicable.

Sources: Authors' calculations. Dates for the default or restructuring episodes taken from Beim and Calomiris (2001) and Standard and Poor's Credit Week (various issues); country ratings are from Institutional Investor (various issues); inflation is calculated from consumer price indices as reported in the IMF's International Financial Statistics.
} 
Today's emerging markets did not invent serial default. It has been practiced in Europe since at least the sixteenth century, as table 2 illustrates. As already noted, Spain defaulted on its debt thirteen times from the sixteenth through the nineteenth centuries, with the first recorded default in 1557 and the last in 1882 . In the nineteenth century alone, Portugal, Germany, and Austria defaulted on their external debts five times, and Greece, with four defaults during that period, was not far behind. France defaulted on its debt eight times between 1550 and 1800. (Admittedly, the French governments' debts were mainly held internally before 1700, and "restructuring" was often accomplished simply by beheading the creditors-giving new meaning to the term "capital punishment."”)

This central fact — that some countries seem to default periodically, and others neverboth compels us to write on this topic and organizes our thinking. True, as we will later illustrate, history is not everything. Countries can eventually outgrow debt intolerance, but the process tends to be exceedingly slow, and backsliding is extremely difficult to avoid. Is Serial Default Really Such a Problem?

What does history tell us about the true costs of default? Might periodic default (or equivalently, restructuring) simply be a mechanism for making debt more equity-like, that is, for effectively indexing a country's debt service to its output performance? After all, defaults

\footnotetext{
${ }^{9}$ Episodes of saignée, or bloodletting, of financiers took place a few years after several of France's defaults, including those of 1558,1624 , and 1661, when particularly prominent creditors of the government were executed; see Bosher (1970) and Bouchard (1891). The authors are grateful to Harold James for these references.
} 
Table 2. An Early History of External Debt Defaults: Europe before the Twentieth Century

\begin{tabular}{|c|c|c|c|c|c|}
\hline & \multicolumn{2}{|c|}{$1501-1800$} & \multicolumn{2}{|r|}{$1801-1900$} & \multirow[b]{2}{*}{$\begin{array}{c}\text { Total } \\
\text { defaults } \\
\end{array}$} \\
\hline & $\begin{array}{c}\text { number of } \\
\text { defaults }\end{array}$ & $\begin{array}{c}\text { years of } \\
\text { default }\end{array}$ & $\begin{array}{c}\text { number of } \\
\text { defaults }\end{array}$ & $\begin{array}{r}\text { years of } \\
\text { default }\end{array}$ & \\
\hline Spain & 6 & $1557,1575,1596$ & 7 & $1820,1831,1834,1851$ & 13 \\
\hline France & 8 & $\begin{array}{l}1607,1627,1647 \\
1558,1624,1648,1661 \\
1701,1715,1770,1788\end{array}$ & n.a. & $1867,1872,1882$ & $8^{\mathrm{a}}$ \\
\hline Portugal & 1 & 1560 & 5 & $\begin{array}{c}1837,1841,1845 \\
1852,1890\end{array}$ & 6 \\
\hline Germany $^{\mathrm{b}}$ & 1 & 1683 & 5 & $\begin{array}{c}1807,1812,1813 \\
1814,1850\end{array}$ & 6 \\
\hline Austria & n.a. & n.a. & 5 & $\begin{array}{c}1802,18051811 \\
1816,1868\end{array}$ & 5 \\
\hline Greece & n.a. & n.a. & 4 & $1826,1843,1860,1893$ & 4 \\
\hline Bulgaria & n.a. & n.a. & 2 & 1886,1891 & 2 \\
\hline Holland & n.a. & n.a. & 1 & 1814 & 1 \\
\hline Russia & n.a. & n.a. & 1 & 1839 & 1 \\
\hline Total & 16 & & 30 & & 46 \\
\hline
\end{tabular}

a Total for the period 1501-1800 only.

b Defaults listed are those for Prussia in 1683, 1807 and 1813, Westfalia in 1812; Hesse in 1814 and SleswigHolstein in 1850.

Notes: An n.a. denotes not available.

Sources: Bosher (1970), Bouchard (1891), Vives (1969), Winkler (1933) and Wynne (1951).

typically occur during economic downturns. ${ }^{10}$ Although there must be some truth to this argument, our reading of history is that the deadweight costs to defaulting on external debt can be significant, particularly for a country's trade, investment flows, and economic growth. In more advanced economies, external default can often cause lasting damage to a country's financial system, not least because of linkages between domestic and foreign financial markets.

\footnotetext{
${ }^{10}$ Bulow and Rogoff (1989) argue that one alternative, namely, formal output indexation clauses, although preferable to nonindexed debt, might be difficult to verify or enforce.
} 
Indeed, although we do not investigate the issue here, we conjecture that one of the reasons why countries without a default history go to great lengths to avoid defaulting is precisely to protect their banking and financial systems. Conversely, weak financial intermediation in many serial defaulters lowers their penalty to default. The lower costs of financial disruption that these countries face may induce them to default at lower thresholds, further weakening their financial systems and perpetuating the cycle. One might make the same comment about tax systems, a point to which we will return at the end of the paper. Countries where capital flight and tax avoidance are high tend to have greater difficulty meeting debt payments, forcing governments to seek more revenue from relatively inelastic tax sources, in turn exacerbating flight and avoidance. Default amplifies and ingrains this cycle.

We certainly do not want to overstate the costs of default or restructuring, especially for serial defaulters. In fact, we will later show that debt-intolerant countries rarely choose to grow or pay their way out of heavy external debt burdens without at least partial default. This revealed preference on the part of debt-intolerant countries surely tells us something. Indeed, many question whether, in the long run, the costs of allowing or precipitating a default exceed the costs of an international bailout, at least for some spectacular historical cases. But there is another side to the question of whether debt-intolerant countries really do borrow too much, and that has to do with the benefit side of the equation. Our reading of the evidence, at least from the 1980s and 1990s, is that external borrowing was often driven by shortsighted governments that were willing to take significant risks to raise consumption temporarily, rather than to foster high-return investment projects. The fact that the gains from borrowing come quickly, whereas the increased risk of default is borne only in the future, tilts shortsighted governments toward excessive debt. So, although the costs of default are indeed often overstated, the benefits to be 
reaped from external borrowing are often overstated even more, especially if one looks at the longer-term welfare of the citizens of debtor countries.

What does history tell us about the lenders? We do not need to tackle this question here. Each of the periodic debt cycles the world has witnessed has had its own unique character, either in the nature of the lender (for example, bondholders in the 1930s and 1990s versus banks in the 1970s and 1980s) or in the nature of the domestic borrower (for example, stateowned railroads in the 1870 s versus core governments themselves in the 1980s). There are, however, clearly established cycles in lending to emerging markets, with money often pouring in when rates of return in industrialized countries are low. Heavy borrowers are particularly vulnerable to "sudden stops," or reversals, when returns in industrial countries once again pick up.

\section{Debt Thresholds}

Few macroeconomists would be surprised to learn that emerging market economies with ratios of external debt to GNP above 150 percent run a significant risk of default. After all, among advanced economies, Japan's current debt-to-GDP ratio, at 120 percent, is almost universally considered high. Yet default can and does occur at ratios of external debt to GNP that would not be considered "excessive" for the typical advanced economy: for example, Mexico's 1982 debt crisis occurred at a ratio of debt to GNP of 47 percent, and Argentina's 2001 crisis at a ratio slightly above 50 percent.

We begin our investigation of the debt thresholds of emerging market economies by chronicling all episodes of default or restructuring of external debt among middle-income 
economies during the period from 1970 to $2001 .^{11}$ Table 3 lists thirty countries that suffered at least one default or restructuring during that period, the first year of each episode, and the country's ratios of external debt to GNP and to exports at the end of the year in which the episode occurred. (Many episodes lasted several years.) It is obvious from the table that Mexico's 1982 default and Argentina's 2001 default were not exceptions: many other countries also suffered adverse credit events at levels of debt below 50 percent of GNP.

\footnotetext{
${ }^{11}$ Following the World Bank, for some purposes we divide developing countries by income per capita into two broad groups: middle-income countries (those developing countries with GNP per capita higher than \$755 in 1999) and low-income countries (those below that level). Most but not all emerging market economies - defined here as developing economies with substantial access to private external financing - are middle-income countries, and most but not all low-income countries have no access to private capital markets and instead rely primarily on official sources of external funding.
} 
Table 3. External Debt Ratios in Middle Income Countries at the Time of Adverse Credit Event: 1970-2001 ${ }^{\mathrm{a} /}$

\begin{tabular}{|c|c|c|c|}
\hline & $\begin{array}{l}\text { Initial year of } \\
\text { credit event }\end{array}$ & $\begin{array}{c}\text { External debt-to-GNP ratio } \\
\text { in initial year }\end{array}$ & $\begin{array}{c}\text { External debt-to-exports ratio } \\
\text { in initial year }\end{array}$ \\
\hline Albania & 1990 & 45.8 & 616.3 \\
\hline \multirow[t]{2}{*}{ Argentina } & 1982 & 55.1 & 447.3 \\
\hline & 2001 & 53.3 & 458.1 \\
\hline Bolivia & 1980 & 92.5 & 246.4 \\
\hline Brazil & 1983 & 50.1 & 393.6 \\
\hline Bulgaria & 1990 & 57.1 & 154.0 \\
\hline \multirow[t]{2}{*}{ Chile } & 1972 & 31.1 & n.a. \\
\hline & 1983 & 96.4 & 358.6 \\
\hline Costa Rica & 1981 & 136.9 & 267.0 \\
\hline Dominican Republic & 1982 & 31.8 & 183.4 \\
\hline \multirow[t]{2}{*}{ Ecuador } & 1982 & 60.1 & 281.8 \\
\hline & 1999 & 89.2 & 239.3 \\
\hline Egypt & 1984 & 112.0 & 282.6 \\
\hline Guyana & 1982 & 214.3 & 337.7 \\
\hline Honduras & 1981 & 61.5 & 182.8 \\
\hline Iran & 1992 & 42.5 & 77.7 \\
\hline Jamaica & 1978 & 48.5 & 103.9 \\
\hline Jordan & 1989 & 179.5 & 234.2 \\
\hline Mexico & 1982 & 46.7 & 279.3 \\
\hline Morocco & 1983 & 87.0 & 305.6 \\
\hline Panama & 1983 & 88.1 & 162.0 \\
\hline \multirow[t]{2}{*}{ Peru } & 1978 & 80.9 & 388.5 \\
\hline & 1984 & 62.0 & 288.9 \\
\hline Philippines & 1983 & 70.6 & 278.1 \\
\hline Poland & 1981 & n.a. & 108.1 \\
\hline Romania & 1982 & n.a. & 73.1 \\
\hline \multirow{2}{*}{ Russian Federation } & 1991 & 12.5 & n.a. \\
\hline & 1998 & 58.5 & 179.9 \\
\hline Trinidad and Tobago & 1989 & 48.1 & 112.8 \\
\hline Turkey & 1978 & 21.0 & 374.2 \\
\hline Uruguay & 1983 & 63.7 & 204.0 \\
\hline \multirow[t]{2}{*}{ Venezuela } & 1982 & 48.6 & 220.9 \\
\hline & 1995 & 44.1 & 147.2 \\
\hline Average & & 70.6 & 254.3 \\
\hline
\end{tabular}

${ }^{\mathrm{a} /}$ Middle income countries defined according to the World Bank, Global Development Finance. A "credit event" is a default on or restructuring of the country's external debt Ratios are computed with end-of-period debt stocks on the initial year of the credit event, which normally biases ratios upwards (since in most cases defaults are accompanied by large real exchange rate depreciations). Credit events in Iraq in 1990, South Africa in 1985 and Yugoslavia in 1983 are not listed in the table because data for the debt ratios are not available.

An n.a. indicates not available

Sources: Debt and GNP come from the World Bank's, Debt Tables and Global Development Finance, dates of the default or restructurings are taken from Beim and Calomiris (2001), Standard and Poor's Credit Week (various issues). 
Table 4 shows further that external debt exceeded 100 percent of GNP in only 13 percent of these episodes, that more than half of the default episodes occurred at ratios of debt to GNP below 60 percent, and that defaults occurred despite debt being less than 40 percent of GNP in 13 percent of episodes. ${ }^{12}$ (Indeed, the external debt-to-GNP thresholds reported in table 3 are biased upward, because the debt-to-GNP ratios corresponding to the year of the credit event are driven up by the real depreciation that typically accompanies the event.)

Table 4. Frequency Distribution of External Debt Ratios in Middle-income Countries at the Time of Default: 1970-2001

\begin{tabular}{cc}
\hline \hline $\begin{array}{c}\text { External debt-to-GNP range in first year } \\
\text { of default or restructuring }\end{array}$ & Percent of total defaults or restructurings \\
\hline \hline Below 40 percent & 13 \\
41 to 60 percent & 40 \\
61 to 80 percent & 13 \\
81 to 100 percent & 20 \\
Above 100 percent & 13 \\
\hline \hline
\end{tabular}

Notes: Middle income countries defined according to the World Bank, Global Development Finance.

All cases marked n.a. in Table 3 are excluded from the calculations. Frequencies do not add to 100 percent due to rounding.

Sources: Table 3 and authors' calculations.

We next compare the external indebtedness profiles of emerging market economies with and without a history of default. The top panel of figure 1 shows the frequency distribution of the external debt-to-GNP ratio, and the bottom panel the external debt-to-exports ratio, for two groups of countries over the period 1970-2000. The two distributions are very distinct

\footnotetext{
12 Tables 3 and 4 measure gross total external debt, as debtor governments have little capacity to tax or otherwise confiscate private citizens' assets held abroad. When Argentina defaulted in 2001 on \$140 billion of external debt, for example, the foreign assets held by its citizens abroad were estimated by some commentators at about $\$ 120$ billion to $\$ 150$ billion. This phenomenon is not uncommon and indeed was the norm in the 1980 s debt crisis.
} 
Figure 1. Frequency Distribution of External Debt Ratios Among Defaulters and Nondefaulters, 1970-2000
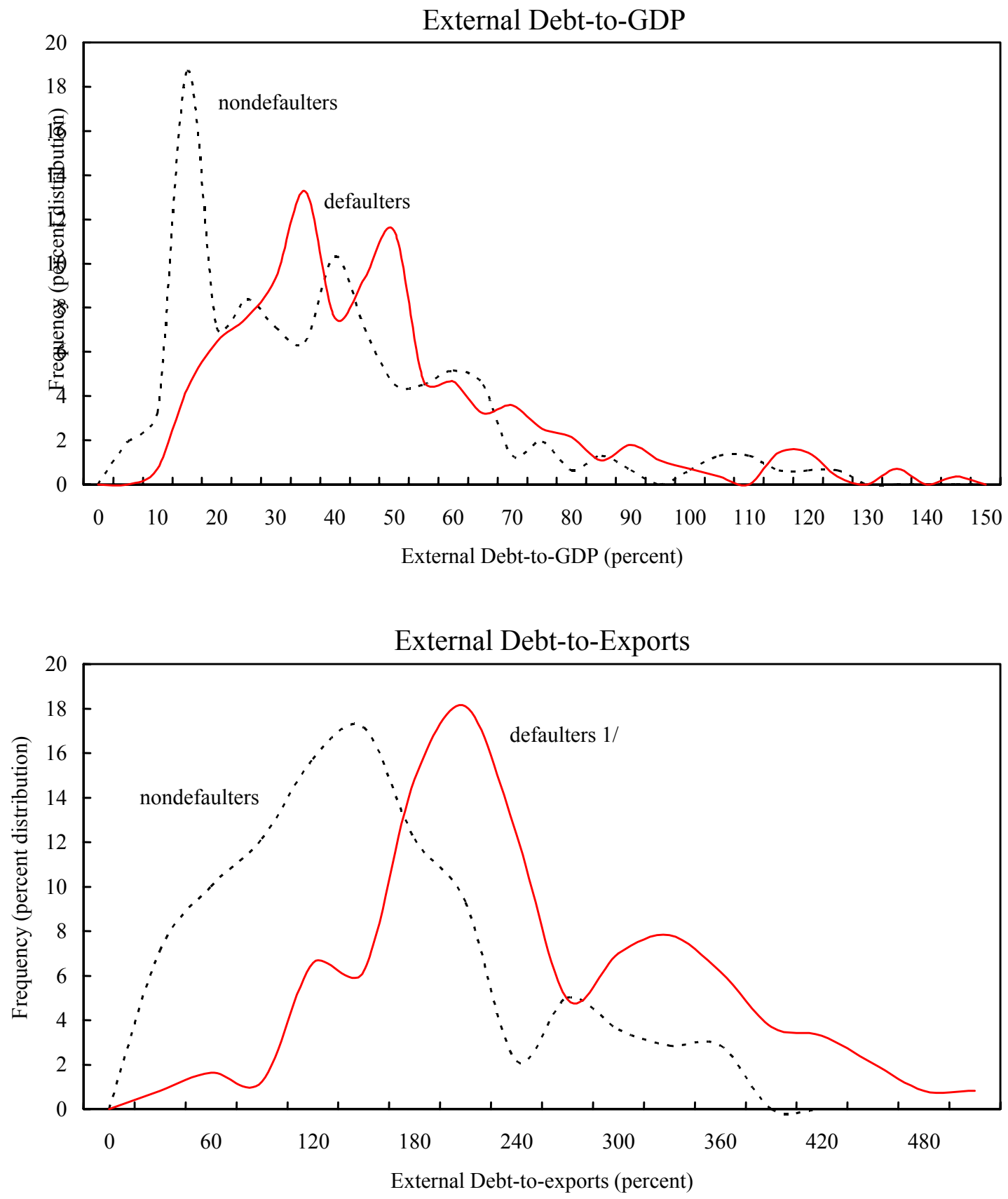

Sources: International Monetary Fund, World Economic Outlook; and the World Bank, Global Development Finance. 1/ The distribution for "defaulters" in the lower panel covers 98 percent of the total observations in the sample. 
and show that defaulters borrow more than nondefaulters (even though their ratings tend to be worse at a given level of debt). The gap in external debt ratios between those emerging market economies with and those without a history of default widens further when the ratio of external debt to exports is considered. It appears that those countries that risk default the most when they borrow (that is, those with the greatest debt intolerance) also borrow the most, much as if a lactose-intolerant individual were addicted to milk. It should be no surprise, then, that so many capital flow cycles end in an ugly credit event.

Table 5 presents a subset of the numbers that underpin figure 1, as well as the cumulative distribution of external debt-to-GNP ratios for defaulters and nondefaulters. Over half of the countries with sound credit histories have ratios of external debt to GNP below 35 percent (and 47 percent have ratios below 30 percent). By contrast, for those countries with a relatively tarnished credit history, a threshold external debt-to-GNP ratio above 40 percent is required to capture the majority of observations. We can see already from tables 4 and 5 , without taking into account any country-specific factors that might explain debt intolerance, that when external debt exceeds 30 to 35 percent of GNP in a debt-intolerant country, the risk of a credit event starts to increase significantly. ${ }^{13}$ We will later derive country-specific bounds that are much stricter for debt-intolerant countries.

\footnotetext{
${ }^{13}$ Using an altogether different approach, an International Monetary Fund (2002) study of debt sustainability arrived at external debt thresholds for developing countries (excluding the heavily indebted poor countries) in the neighborhood of 31 to 39 percent, depending on whether one includes official financing in the indebtedness measure. The results we present later suggest that country-specific thresholds for debt-intolerant countries are probably much lower.
} 
Table 5. Frequency Distribution of External Debt Ratios in Emerging Market Economies: 1970-2000

\begin{tabular}{|c|c|c|c|c|}
\hline \multirow{2}{*}{$\begin{array}{c}\text { External debt-to- } \\
\text { GNP Ratio } \\
\text { (in percent) } \\
\end{array}$} & \multicolumn{2}{|c|}{$\begin{array}{c}\text { Economies without a history of external } \\
\text { default }\end{array}$} & \multicolumn{2}{|c|}{ Economies with history of external default } \\
\hline & $\begin{array}{l}\text { Density } \\
\text { (percent of } \\
\text { countries) }\end{array}$ & $\begin{array}{l}\text { Cumulative } \\
\text { distribution }\end{array}$ & $\begin{array}{l}\text { Density } \\
\text { (percent of } \\
\text { countries) } \\
\end{array}$ & $\begin{array}{l}\text { Cumulative } \\
\text { distribution }\end{array}$ \\
\hline 0 & 0 & 0 & 0 & 0 \\
\hline 5 & 1.9 & 1.9 & 0 & 0 \\
\hline 10 & 3.2 & 5.2 & 0.7 & 0.7 \\
\hline 15 & 18.7 & 23.9 & 4.3 & 5.0 \\
\hline 20 & 7.1 & 31.0 & 6.5 & 11.5 \\
\hline 25 & 8.4 & 39.4 & 7.5 & 19.0 \\
\hline 30 & 7.1 & 46.5 & 9.3 & 28.3 \\
\hline 35 & 6.5 & 52.9 & 13.3 & 41.6 \\
\hline 40 & 10.3 & 63.2 & 7.5 & 49.1 \\
\hline 45 & 7.1 & 70.3 & 9.3 & 58.4 \\
\hline 50 & 4.5 & 74.8 & 11.5 & 69.9 \\
\hline \multicolumn{5}{|l|}{ Memoranda } \\
\hline Mode & \multicolumn{2}{|c|}{14.0} & \multicolumn{2}{|c|}{28.0} \\
\hline Median & \multicolumn{2}{|c|}{33.3} & \multicolumn{2}{|c|}{40.9} \\
\hline
\end{tabular}

Sources: Authors' calculations on the basis of debt and GNP data from the World Bank, Global Development Finance.

The Components of Debt Intolerance

To operationalize the measurement of debt intolerance, we focus on two indicators: the sovereign debt ratings reported by Institutional Investor, and the external debt-to-GNP ratio (or, alternatively, the external debt-to-exports ratio). The Institutional Investor ratings (IIR), which are compiled twice a year, are based on information provided by economists and sovereign risk analysts at leading global banks and securities firms. The ratings grade each country on a scale from 0 to 100 , with a rating of 100 given to those countries perceived as having the lowest 
chance of defaulting on their government debt obligations. ${ }^{14}$ Hence we take the transformed variable (100 - IIR) as a proxy for default risk. Market-based measures of default risk are also available, but only for a much smaller group of countries and over a much shorter sample period. $^{15}$

The second major component of our debt intolerance measure is total external debt, scaled either by GNP or by exports. We emphasize total (public and private) external debt because most government debt in emerging markets until the late 1980s was external, and because it often happens that external debt that was private before a crisis becomes public after the fact. ${ }^{16}$ (As we later show, however, in future analyses it will be equally important to measure intolerance with reference to the growing stock of domestic public debt.)

Figure 2 plots against each other the major components of debt intolerance for each year in the period 1979-2000 for sixteen emerging market economies. As expected, our preferred risk measure (100 - IIR) tends to rise with the stock of external debt, but the relationship may be nonlinear. In particular, when the risk measure is very high (concretely, when the IIR index

\footnotetext{
${ }^{14}$ For details of the survey see the September 2002 issue of Institutional Investor. Although not critical to our analysis below, we interpret the ratings reported in each semiannual survey as capturing the near-term risk of default within one to two years.

${ }^{15}$ Secondary market prices of external commercial bank debt, available since the mid-1980s, provide a measure of expected repayment for a number of emerging market countries. However, the Brady debt restructurings of the 1990s converted much of this bank debt to bonds, so that from 1992 onward the secondary market prices would have to be replaced by the Emerging Market Bond Index (EMBI) spread, which remains the most commonly used measure of risk today. These market-based indicators introduce a serious sample selection bias, however: almost all the countries in the EMBI, and all the countries for which secondary-market price data from the 1980s are available, had a history of adverse credit events, leaving the control group of nondefaulters as approximately the null set.

${ }^{16}$ See appendix A for brief definitions of the various concepts of debt used in this paper.
} 


\section{Figure 2. External Debt and Default Risk In Selected Emerging Market Economies, 1979-2000}

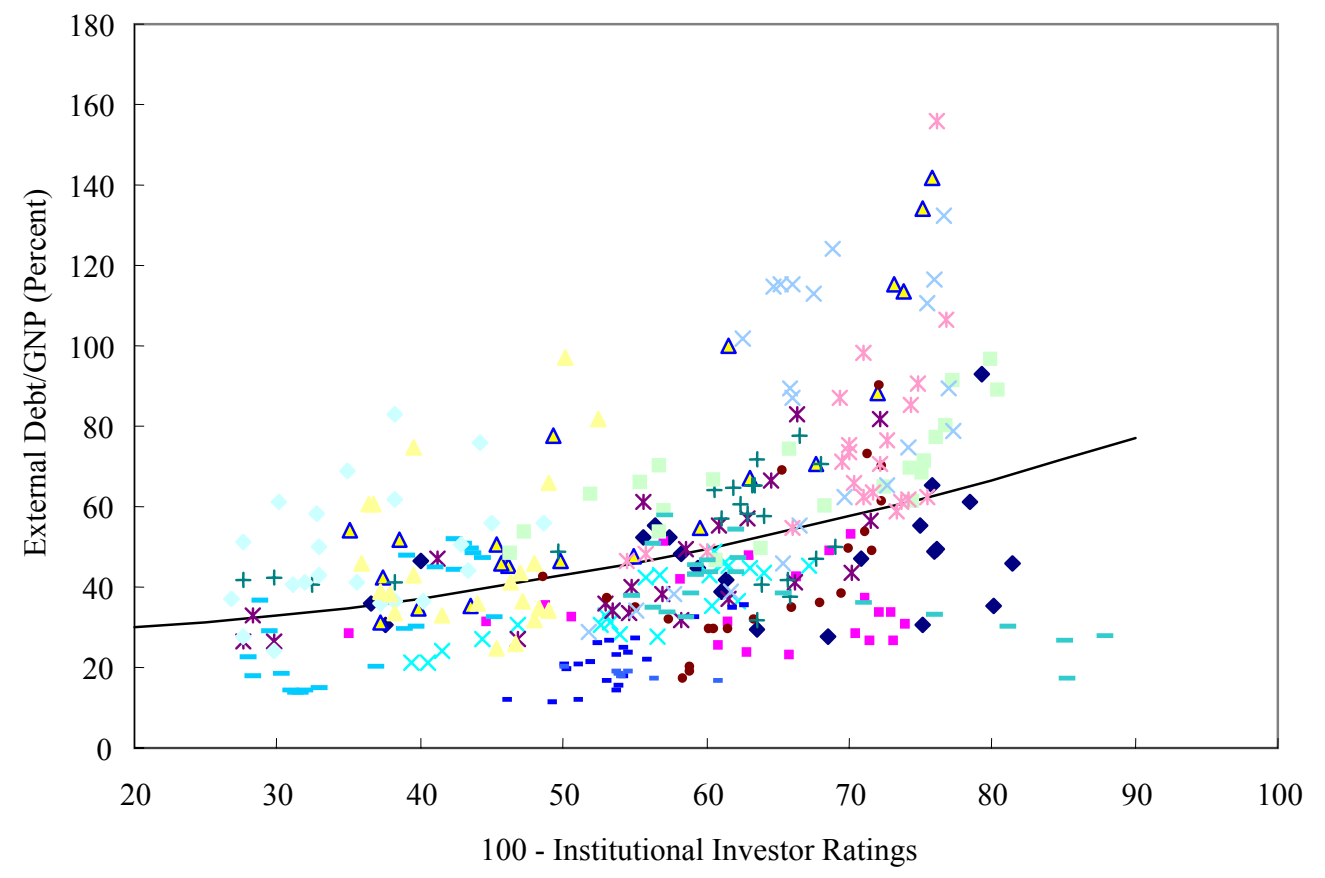

- Argentina

- Brazil

$\Delta$ Chile

$\times$ Colombia

* Mexico

- Uruguay

+ Venezuela

- India

- Korea

Malaysia

Philippines

Thailand

Egypt

* Kenya

- South Africa

- Turkey

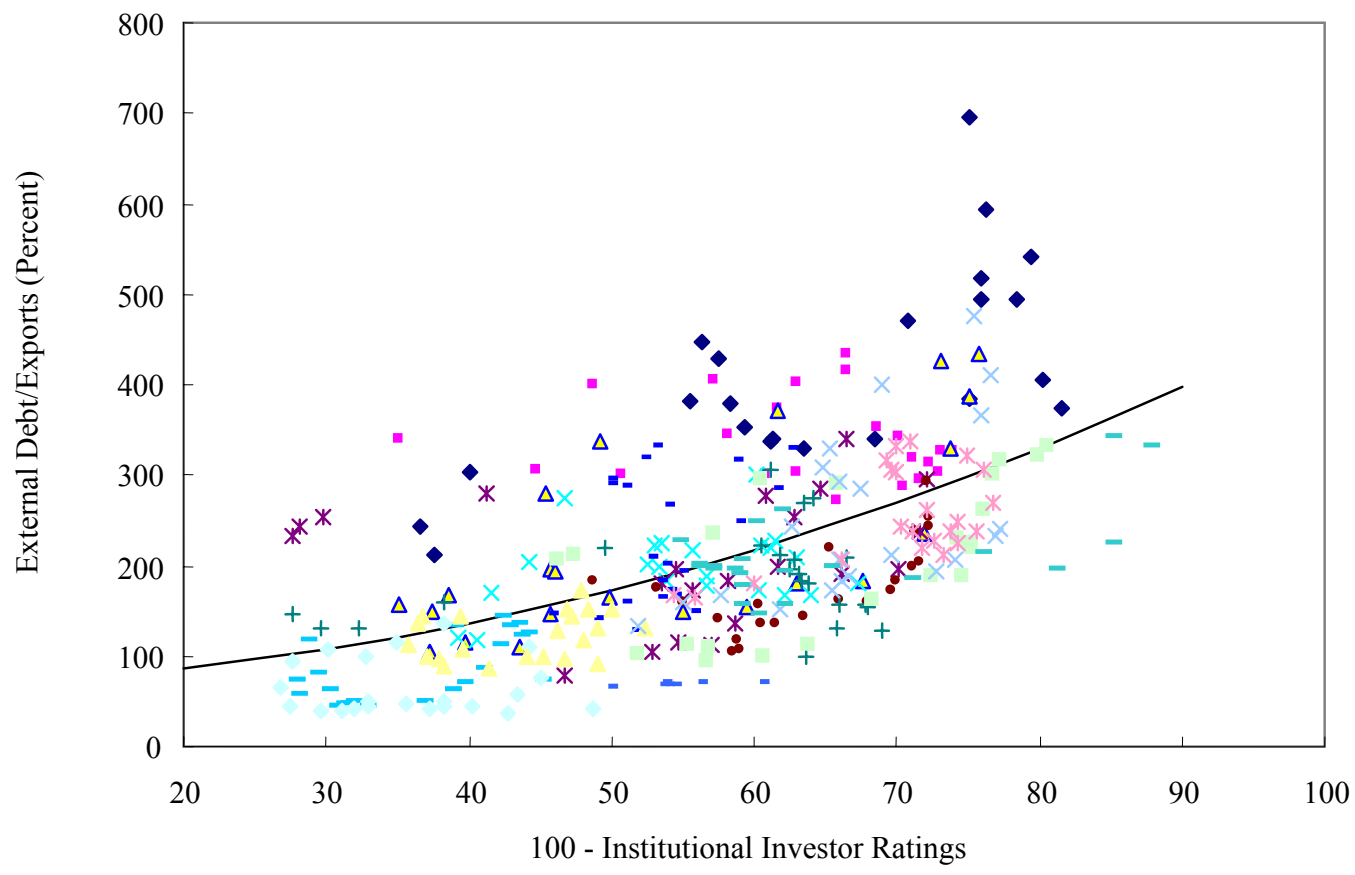

- Argentina

- Brazil

$\Delta$ Chile

$\times$ Colombia

* Mexico

- Uruguay

+ Venezuela

- India

- Korea

Malaysia

Philippines

Thailand

$\times$ Egypt

* Kenya

- South Africa

- Turkey

Sources; World Bank, Global Development Finance; and Institutional Investor. 
falls below 30), it matters little whether the external debt-to-GNP ratio is 80 percent or 160 percent, or whether the external debt-to-exports ratio is 300 percent or 700 percent. This nonlinearity simply reflects the fact that, below a certain threshold of the IIR, typically about 24 , the country has usually lost all access to private capital markets. ${ }^{17}$

Table 6 shows the period averages of various measures of risk and external debt (the components of debt intolerance) for a representative sample of countries, which we will refer to as our core sample (see appendix B). Because some researchers have argued that the "right" benchmark for emerging market indebtedness is the level of public debt that advanced economies are able to sustain, ${ }^{18}$ table 6 also includes this measure for a group of nondefaulting advanced economies. The table makes plain that, although the relationship between external debt and risk may be monotonic for emerging market economies, it is clearly not monotonic for the public debt of advanced economies; in those countries, relatively high levels of government debt can coexist with low levels of risk. Table 6 , together with table 7 , which shows the panel pairwise correlations between the two debt ratios and three measures of risk for a larger sample of developing economies, also highlights the fact that the different measures of risk present a very similar picture both of countries' relative debt intolerance and of the correlation between risk and indebtedness. As anticipated by figure 2, the correlations are uniformly positive in all regional groupings and are usually statistically significant.

\footnotetext{
${ }^{17}$ A similar picture emerges (for a smaller sample, not shown) when one uses other measures of default risk such as secondary market prices of commercial bank debt or EMBI spreads.

${ }^{18}$ See, for example, Reissen (1989).
} 
Table 6. Alternative Measures of Risk and External Debt Burden: (Period averages, as indicated)

\begin{tabular}{|c|c|c|c|c|c|}
\hline & $\begin{array}{c}\text { Institutional } \\
\text { Investor Ratings } \\
\text { 1979-2002 }\end{array}$ & $\begin{array}{c}\text { Secondary market } \\
\text { prices } \\
1986-1992\end{array}$ & EMBI spread $^{\text {a }}$ & $\begin{array}{l}\text { Debt/GNP } \\
1970-2000 \\
\text { (in percent) }\end{array}$ & $\begin{array}{c}\text { Debt/Exports } \\
1970-2000 \\
\text { (in percent) }\end{array}$ \\
\hline \multicolumn{6}{|c|}{ Emerging market economies with at least one external default or restructuring since 1824} \\
\hline Argentina & 34.7 & 34.9 & 1,756 & 37.1 & 368.8 \\
\hline Brazil & 37.4 & 42.9 & 845 & 30.7 & 330.7 \\
\hline Chile & 47.5 & 70.8 & 186 & 58.4 & 220.7 \\
\hline Colombia & 44.6 & 71.4 & 649 & 33.6 & 193.5 \\
\hline Egypt & 33.7 & n.a. & 442 & 70.6 & 226.7 \\
\hline Mexico & 45.8 & 56.0 & 593 & 38.2 & 200.2 \\
\hline Philippines & 34.7 & 54.4 & 464 & 55.2 & 200.3 \\
\hline Turkey & 34.9 & n.a. & 663 & 31.5 & 210.1 \\
\hline Venezuela & 41.5 & 59.6 & 1,021 & 41.3 & 145.9 \\
\hline Group average & 39.4 & 55.7 & 638 & 44.1 & 232.9 \\
\hline \multicolumn{6}{|c|}{ Emerging market economies with no external default history } \\
\hline India & 46.5 & n.a. & n.a. & 19.0 & 227.0 \\
\hline Korea & 63.4 & n.a. & 236 & 31.9 & 85.7 \\
\hline Malaysia & 63.5 & n.a. & 166 & 40.1 & 64.9 \\
\hline Singapore & 79.9 & n.a. & n.a. & 7.7 & 4.5 \\
\hline Thailand & 55.7 & n.a. & 240 & 36.3 & 110.8 \\
\hline Group average & 61.8 & n.a. & 214 & 27.0 & 98.6 \\
\hline \multicolumn{6}{|c|}{ Industrial economies with no external default history ${ }^{\mathrm{b}}$} \\
\hline Australia & 77.3 & n.a. & n.a. & 29.8 & 159.3 \\
\hline Canada & 86.0 & n.a. & n.a. & 68.9 & 234.4 \\
\hline Italy & 76.4 & n.a. & n.a. & 81.6 & 366.0 \\
\hline New Zealand & 70.7 & n.a. & n.a. & 51.9 & 167.3 \\
\hline Norway & 85.3 & n.a. & n.a. & 34.4 & 87.5 \\
\hline United States & 92.8 & n.a. & n.a. & 58.4 & 671.7 \\
\hline Group average & 81.3 & n.a. & n.a. & 54.2 & 281.0 \\
\hline
\end{tabular}

\footnotetext{
${ }^{a}$ The EMBI averages are through 2002. The beginning date varies by country and is as follows: Argentina 1993; Brazil, Mexico, and Venezuela 1992; Chile, Colombia and Turkey 1999; Egypt and Malaysia 2002; Philippines and Thailand 1997, and Korea 1998.

b For industrial economies debt figures are for the total debt issued by the general government .

Notes: An n.a. stands for not available.

Sources: World Bank, Global Development Finance, Institutional Investor, JP Morgan Chase, Salomon Brothers, Inc., ANZ Bank Secondary Market Price Report, and OECD.
} 
Table 7. Pairwise Correlations between Alternative Measures of Risk and Debt by Developing Region

\begin{tabular}{ccc}
\hline \hline 100-Institutional & 100-Secondary & EMBI Spread $^{a}$ \\
Investor Ratings & Market Prices & \\
1979-2000 & $1986-1992$ & \\
\hline \hline
\end{tabular}

Correlations with External debt-to-GNP

$\begin{array}{llcc}\text { All developing } & 0.40^{*} & 0.47^{*} & 0.55^{*} \\ \text { Africa } & 0.22 & 0.65^{*} & 0.73^{*} \\ \text { Emerging Asia } & 0.44^{*} & \text { n.a. } & \text { n.a. } \\ \text { Middle East } & 0.18 & \text { n.a. } & \text { n.a. } \\ \text { Western Hemisphere } & 0.38^{*} & 0.50^{*} & 0.45^{*}\end{array}$

Correlations with External debt-to-exports

\begin{tabular}{lccc} 
All developing & $0.61^{*}$ & $0.58^{*}$ & $0.37^{*}$ \\
Africa & $0.60^{*}$ & $0.59^{*}$ & $0.67^{*}$ \\
Emerging Asia & $0.74^{*}$ & n.a. & n.a. \\
Middle East & $0.51^{*}$ & n.a. & n.a. \\
Western Hemisphere & $0.43^{*}$ & $0.59^{*}$ & 0.06 \\
\hline
\end{tabular}

Notes: An asterisk denotes that the correlation is statistically significant at the five percent confidence level.

An n.a. stands for not available.

${ }^{\text {a }}$ Defined as in Table 6. Excludes Russia.

Sources: World Bank, Global Development Finance, Institutional Investor, JP Morgan

Chase, Salomon Brothers, Inc., ANZ Bank Secondary Market Price Report.

\section{Debt Intolerance: Clubs and Regions}

We next use our component measures of debt intolerance-IIR risk ratings and external debt ratios - in a two-step algorithm, mapped in figure 3, to define debtors' clubs and vulnerability regions. We begin by calculating the mean (45.9) and standard deviation (21.8) of the IIR for fifty-three developing and industrial countries over 1979-2002, and we use these statistics to loosely group countries into three "clubs" (the countries and their period averages are listed in appendix table B1). Club A includes those countries whose average IIR over the period 1979-2002 is 67.7 (the mean plus one standard deviation) or above; members of this club-essentially, the advanced economies - enjoy virtually continuous access to capital 
markets. As their repayment history and debt absorption capacity show (tables 1and 3), these countries are the least debt intolerant. At the opposite extreme, in club C, are those countries whose average IIR is below 24.2 (the mean minus one standard deviation). This club includes those countries that are so debt intolerant that markets give them only sporadic opportunities to borrow; hence their primary sources of external financing are grants and official loans.

Club B includes the remaining countries and are the main focus of our analysis. These countries exhibit varying degrees of debt intolerance. ${ }^{19}$ They occupy the "indeterminate" region of theoretical debt models, the region where default risk is nontrivial, and where self-fulfilling debt runs may trigger a crisis. Club B is large and includes both countries that are on the cusp of graduation to club A as well as countries that may be on the brink of default. The membership of club B therefore requires further discrimination. Our preferred creditworthiness measure, 100- IIR, is no longer a sufficient statistic, and information on the extent of leveraging (the second component of debt intolerance) is necessary to pin down more precisely the relative degree of debt intolerance within this club.

Hence, in the second step, our algorithm further subdivides the "indeterminate" club B into four "regions," ranging from least to most debt intolerant. The region of least debt intolerance (which we call region I) includes those countries whose average IIR over 19792002 was above the mean and whose ratio of external debt to GNP was below 35 percent. (As previously noted, countries below that threshold account for over half of the observations among nondefaulters over 1970-2001.) Region II includes countries whose average IIR is

\footnotetext{
${ }^{19}$ One is reminded of Groucho Marx's aphorism, "I don't care to belong to any club that will have me as a member." As will be shown, membership in club B is not a privilege.
} 


\section{Figure 3. Defining Debtors' Clubs and External Debt Intolerance Regions}

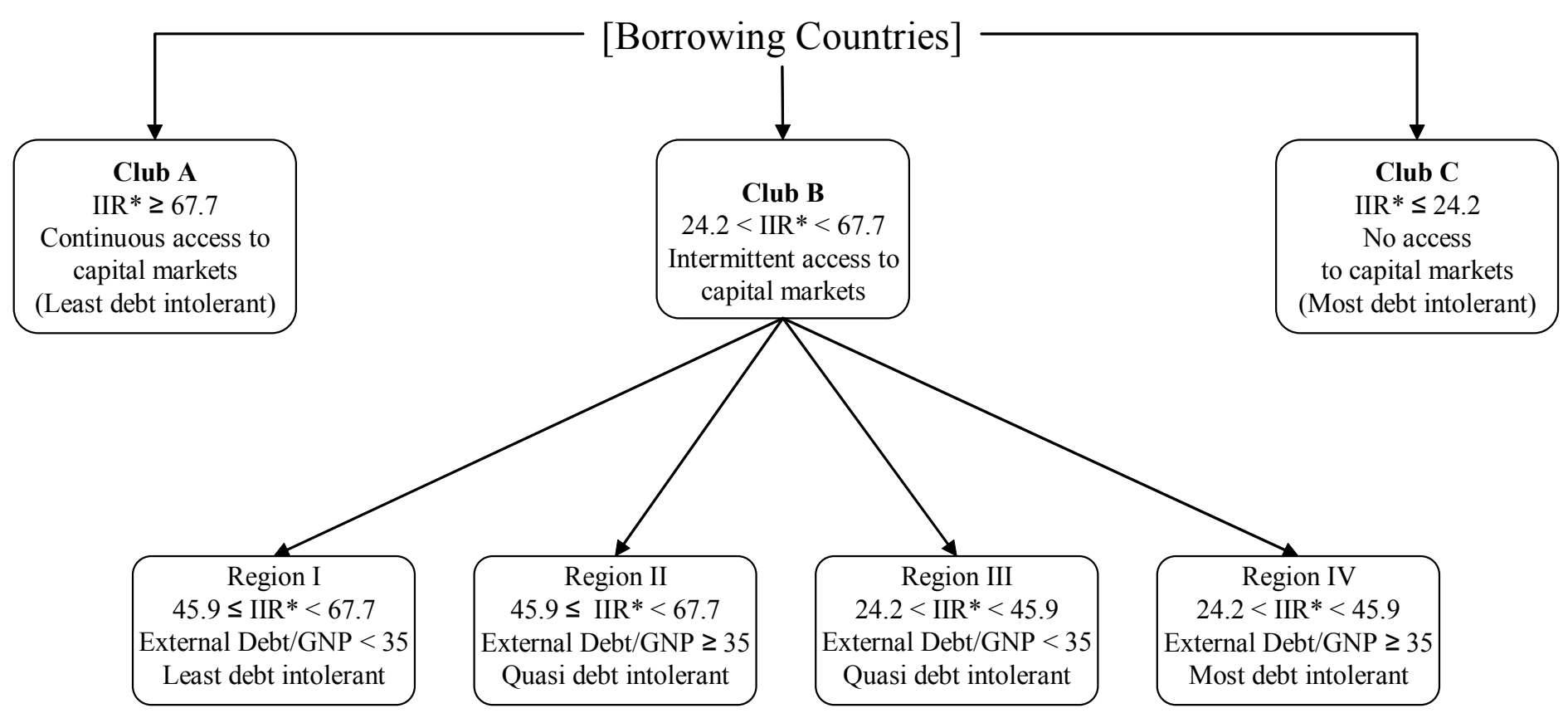

* IIR = Average value for Institutional Investors' Ratings over the period 1979-2002 
above the mean but whose external debt-to-GNP ratio is above 35 percent. Because their higher-than-average long run creditworthiness enables them to sustain a higher-than-average external debt burden, this is the second-least debt-intolerant group. More debt intolerant still are the region III countries, whose long-run creditworthiness (as measured by their average IIR) is below the mean and whose external debt is below 35 percent of GNP. Lastly, the countries in Club B with the highest debt intolerance are those in region IV, with an average IIR below the mean and external debt levels above 35 percent of GNP. Countries in region IV can easily fall into club C, losing their market access to credit. For example, in early 2000 Argentina's IIR was 43 and its external debt-to-GNP ratio was 51 percent, making it a region IV country. As of September 2002, Argentina's IIR had dropped to 15.8, indicating that the country had backslid into club C. As we will see, countries do not graduate to higher clubs easily; indeed, it can take many decades of impeccable repayment performance and low debt levels to graduate from club B to club A.

\section{DEBT InTOLERANCE: THE ROLE OF HISTORY}

We begin this section by offering some basic insights into the historical origins of country risk, which some have mislabeled as "original sin.. ${ }^{20}$ In particular, we focus on countries' credit and inflation histories. We then use our core results for several purposes: to illustrate how to calculate country-specific debt thresholds, in contrast to the coarse threshold (an external debt-to-GNP ratio of 35 percent) derived earlier; to show how countries in club B shift between debt intolerance regions over time; to illustrate how countries may graduate into a

\footnotetext{
${ }^{20}$ See, for example, Eichengreen, Hausmann, and Panizza (2002).
} 
better club; and to show how a simple summary statistic can rank countries within club B according to their relative degree of debt intolerance.

\section{Historical Determinants of Country Risk}

To prepare to investigate econometrically the link between a country's external credit and inflation history, on the one hand, and its sovereign risk, on the other, we broaden our sample from the twenty countries listed in table 6 to the fifty-three industrial and developing economies listed in appendix table B1. The IIR rating, our preferred measure of creditworthiness, is the dependent variable in all the regressions. To measure a country's credit history, we calculate the percentage of years in the sample when the country was either in default on its external debt or undergoing a restructuring of its debt. Two different periods are analyzed: 1824-1999 and 1946-1999. Another indicator of credit history we use is the number of years since the country's last default or restructuring on its external debt. We also calculate for each country the percentage of twelve-month periods during 1948-2000 when annual inflation was above 40 percent. $^{21}$ Although it is quite reasonable to expect that debt intolerance may itself lead to a higher probability of default (because markets charge a higher premium on borrowing) or a higher probability of inflation (because often the country has few other sources of deficit financing), we are not too concerned about the potential endogeneity of these two regressors, because they are largely predetermined relative to the main sample period, which is $1979-2000 .^{22}$

\footnotetext{
${ }^{21}$ For a discussion of why 40 percent seems a reasonable threshold for high inflation, see Easterly (2001) and Reinhart and Rogoff (2002).

${ }^{22}$ An obvious way of extending this analysis of credit history would be to distinguish between peacetime and wartime defaults and gather additional information about governments' violation of other contracts, such as
} 
However, using 1970-2000 averages of the external debt-to-GNP ratio (or the external debt-to-exports ratio) as a regressor does pose a potential endogeneity problem. Therefore we report the results of both ordinary least-squares and instrumental variable estimations, in the latter case using the average debt-to-GNP ratio during 1970-78 as an instrument. Because White's test revealed heteroskedasticity in the residuals, we correct accordingly to ensure the consistency of the standard errors. To investigate whether the differences in debt tolerance between countries in club $\mathrm{A}$ and the rest of the sample are systematic, we also use a dummy variable for club $\mathrm{A}$ in the regressions, allowing the club A countries to have a different slope coefficient on the debt-to-GNP ratio.

Table 8 presents the results of six different specifications of the cross-country regressions. The results show that few variables suffice to account for a significant portion (about 75 percent) of the cross-country variation in creditworthiness as measured by the IIR. As expected, a poor track record on repayment or inflation lowers the rating and increases risk. In the regressions, all but the debt-to-GNP coefficients are constrained to be the same for club A and all other countries. One common and robust result across these regressions is that the external debt-to-GNP ratio enters with a negative (and significant) coefficient for all the countries in clubs $\mathrm{B}$ and $\mathrm{C}$, whereas it has a positive coefficient for the advanced economies in club $\mathrm{A}^{23}$ As we will show next, this result is robust to the addition of a time dimension to the

defaults on domestic debt or forcible conversions of dollar deposits into local currency (as occurred in Bolivia in 1982, Mexico in 1982, Peru in 1985, and Argentina in 2002).

${ }^{23}$ The estimated coefficient for the club A countries captures both institutional and structural factors specific to those countries as well as the different concept of debt (total public debt as opposed to total external debt) used for those cases (see appendix A). 
regressions. Although not reported here, these results are equally robust to the use of the

external debt-to-exports ratio in lieu of the external debt-to-GNP ratio as a regressor.

Table 8. External Debt, Risk, and Debt Intolerance: The Role of History and "Clubs:" Cross-Section Results

\footnotetext{
subscript $\mathrm{i}$ denotes the country, and $\mathrm{u}_{\mathrm{i}}$ is a disturbance term.

$\mathrm{Y}=$ Institutional Investor Ratings (1979-2000 average).

$\mathrm{X}_{1}=$ Percent of 12-month periods of inflation at or above 40 percent since 1948 .

$\mathrm{X}_{2}=$ Percent of years in a state of default or restructuring since 1824 .

$\mathrm{X}_{3}=$ Percent of years in a state of default or restructuring since 1946.

$\mathrm{X}_{4}=$ Number of years since last default or restructuring.

$\mathrm{X}_{5}=$ External debt/GNP (1970-2000 average) $\mathrm{x}$ Non-Club A Dummy

$\mathrm{X}_{6}=$ Debt/GNP (1970-2000 average) $\mathrm{x}$ Club A Dummy

53 observations
}

The regression is: $Y_{i}=\alpha+\beta_{1} X_{1 i}+\beta_{2} X_{2 i}+\beta_{3} X_{3 i}+\beta_{4} X_{4 i}+\beta_{5} X_{5 i}+\beta_{6} X_{6 i}+u_{i}$, where the Xs are defined below, the

\begin{tabular}{|c|c|c|c|c|c|c|c|}
\hline $\begin{array}{c}\text { Regression } \\
\text { Number }\end{array}$ & $X_{1}$ & $X_{2}$ & $X_{3}$ & $X_{4}$ & $X_{5}$ & $X_{6}$ & Adjusted $R^{2}$ \\
\hline \multicolumn{8}{|c|}{ Least Squares Estimates, Robust Errors } \\
\hline 1 & $\begin{array}{c}-0.16 \\
(-2.97)\end{array}$ & $\begin{array}{c}-0.21 \\
(-2.10)\end{array}$ & & & $\begin{array}{c}-0.33 \\
(-5.40)\end{array}$ & $\begin{array}{c}0.28 \\
(3.63)\end{array}$ & 0.77 \\
\hline 2 & $\begin{array}{c}-0.16 \\
(-1.87)\end{array}$ & & $\begin{array}{c}-0.17 \\
(-1.53)\end{array}$ & & $\begin{array}{c}-0.34 \\
(-4.49)\end{array}$ & $\begin{array}{c}0.29 \\
(3.68)\end{array}$ & 0.76 \\
\hline 3 & $\begin{array}{c}-0.11 \\
(-1.37)\end{array}$ & & & $\begin{array}{c}0.05 \\
(1.93)\end{array}$ & $\begin{array}{c}-0.29 \\
(-4.03)\end{array}$ & $\begin{array}{c}0.27 \\
(3.62)\end{array}$ & 0.79 \\
\hline \multicolumn{8}{|c|}{ Instrumental Variable Estimates, Robust Errors } \\
\hline 4 & $\begin{array}{c}-0.14 \\
(-1.93)\end{array}$ & $\begin{array}{c}-0.12 \\
(-1.33)\end{array}$ & & & $\begin{array}{c}-0.41 \\
(-3.52)\end{array}$ & $\begin{array}{c}0.31 \\
(2.12)\end{array}$ & 0.74 \\
\hline 5 & $\begin{array}{c}-0.13 \\
(-1.26)\end{array}$ & & $\begin{array}{c}-0.12 \\
(-0.86)\end{array}$ & & $\begin{array}{c}-0.39 \\
(-2.51)\end{array}$ & $\begin{array}{c}0.34 \\
(2.30)\end{array}$ & 0.74 \\
\hline 6 & $\begin{array}{c}-0.08 \\
(-0.65)\end{array}$ & & & $\begin{array}{c}0.05 \\
(1.91)\end{array}$ & $\begin{array}{c}-0.33 \\
(-2.02)\end{array}$ & $\begin{array}{c}0.33 \\
(2.23)\end{array}$ & 0.77 \\
\hline
\end{tabular}

Notes: $t$-statistics in parentheses. Clubs are as defined in Figure 3. Appendix Table B1 lists the countries within each club

Sources: Beim and Calomiris (2001), Institutional Investor, IMF's International Financial Statistics, Standard and Poor's Credit Week (various issues), and authors' calculations. 
We also performed two panel regressions (estimated with fixed effects and robust standard errors) in which the IIR was regressed against the external debt-to-GNP ratio and three dummy variables representing periods roughly corresponding to the phases of the most recent debt cycle. The results are as follows:

$\mathrm{IIR}_{i t}=\alpha_{\mathrm{it}}-3.01 X_{1}-12.22 X_{2}-7.01 X_{3}-0.13 X_{4}$

$\begin{array}{llll}(-2.06) & (-8.98) & (-5.13) & (-10.37)\end{array}$

Adjusted $\mathrm{R}^{2}=0.78 ; N=769$

$\mathrm{IIR}_{i t}=\alpha_{\mathrm{it}}-3.61 X_{1}-12.33 X_{2}-6.62 X_{3}-0.11 X_{4}+0.01 X_{5}$ $\begin{array}{lllll}(-2.90) & (-10.69) & (-5.60) & (-9.24) & (0.04)\end{array}$

Adjusted $\mathrm{R}^{2}=0.91 ; N=1,030$ ( $t$ statistics in parentheses).

In these regressions, $\alpha_{\text {it }}$ are the country-specific fixed effects (see Appendix D), $X_{1}$ is a dummy variable for the period immediately before the 1980 s debt crisis (1980-82), $X_{2}$ is a dummy for the period during the crisis and the Brady plan resolution (1983-93), $X_{3}$ is a dummy for the period after the crisis (1994-2000), $X 4$ interacts the country's external debt-to-GNP ratio with a dummy variable for clubs $\mathrm{B}$ and $\mathrm{C}$, and $X_{5}$ interacts the debt-to-GNP ratio with a dummy for club A; $i$ and $t$ index countries and years, respectively. Regressions including year-by-year dummies (reported in appendix tables D1 and D3) reveal that the IIR data naturally demarcate these three distinct subperiods. The first of the two regressions above includes thirty-eight of the fifty-three countries in the cross-sectional regressions (the countries in clubs B and C), whereas the second regression also includes the fifteen countries in club A and (as before) allows them to have a different slope coefficient on the debt-to-GNP ratio, in addition to a different intercept.

The panel regressions (including those reported in Appendix D) confirm a central finding of the cross-sectional regressions: debt is significantly and negatively related to the 
perceived creditworthiness of the debt-intolerant countries in clubs B and C. In contrast, in the regression that includes the advanced economies, which make up most of club A, the coefficient on debt is positive-although, unlike in the cross-sectional results, it is not statistically significant. The coefficients for the three subperiods are all statistically significant and their pattern have an intuitive interpretation. Average IIRs were higher across the board before the debt crisis of the 1980s; these ratings then plummeted as the debt crisis unfolded, and recovered only partially in the 1990s, never quite reaching their precrisis levels. Thus, debt intolerance is long lived.

\section{Country-Specific Debt Thresholds}

We now use some of our core results to illustrate that, although an external debt-to-output ratio of 35 percent is a minimal debt "safety" threshold for those countries that have not made it to club A, countries with a weak credit history may become highly vulnerable even at much lower levels of external debt. To illustrate this basic but critical point, we perform the following exercise. We use the estimated coefficients from the first regression in table 8 , together with the actual values of the regressors, to predict values of the IIR for varying ratios of external debt to GNP for each country. Table 9 illustrates the exercise for the cases of Argentina and Malaysia for levels of external debt ranging from 0 to 45 percent of GNP. Until Argentina's default in December 2001, both countries were members of club B. 
Table 9. Predicted Institutional Investor Ratings and Debt Intolerant Regions for Argentina and Malaysia

\begin{tabular}{ccccc}
\hline \hline & \multicolumn{2}{c}{ Argentina } & \multicolumn{2}{c}{ Malaysia } \\
\cline { 2 - 5 } $\begin{array}{c}\text { External debt/GNP } \\
\text { (percent) }\end{array}$ & $\begin{array}{c}\text { Predicted } \\
\text { Institutional } \\
\text { Investor Rating }\end{array}$ & $\begin{array}{c}\text { Region } \\
\text { Type }\end{array}$ & $\begin{array}{c}\text { Predicted } \\
\text { Institutional } \\
\text { Investor Rating }\end{array}$ & $\begin{array}{c}\text { Region } \\
\text { Type }\end{array}$ \\
\hline \hline & & & & \\
0 & 51.4 & I & 61.1 & I \\
5 & 49.3 & I & 59.0 & I \\
10 & 47.3 & I & 57.0 & I \\
15 & 45.2 & III & 54.9 & I \\
20 & 43.2 & III & 52.9 & I \\
25 & 41.1 & III & 50.8 & IV \\
30 & 39.1 & III & 48.8 & IV \\
35 & 37.0 & III & 46.7 & \\
40 & 34.9 & IV & 44.7 & 42.6 \\
45 & 32.9 & IV & & \\
\hline
\end{tabular}

Notes: Authors calculations are based on the coefficients from regression (1) in Table 8.

For countries in club B [24.2< Institutional Investor Rating (IIR) $<67.7]$ the four regions (from least to most vulnerable) defined in Figure 3 are: Least debt intolerant, Type I $(45.9 \leq \mathrm{IIR}<67.7$ and Debt/GNP $<35)$; quasi debt intolerant, Type II $(45.9 \leq$ IIR $<67.7$ and Debt/GNP $>35)$; quasi debt intolerant, Type III $(25.2 \leq$ IIR $<45.9$ and Debt/GNP $<35)$ and; most debt intolerant Type IV $(25.2 \leq$ IIR $<45.9$ and Debt/GNP $>35$.

The exercise shows clearly that Argentina's precarious debt intolerance situation is more severe than Malaysia's. Argentina remains in the relatively safe region I only as long as its external debt remains below 15 percent of GNP, whereas Malaysia remains in region I up to a debt-to GNP ratio of 30 percent, and it is still in the relatively safe region II with a debt of 35 percent of GNP. These contrasting patterns can be seen across a number of other cases (results not shown): Argentina is representative of the many countries with a relatively weak credit and inflation history, whereas Malaysia is representative of countries with no history of default or high inflation. 


\section{Moving between Debt Intolerance Regions}

To illustrate how countries in club B can become more or less vulnerable over time, table 10 presents an exercise similar to that in table 9 for the case of Brazil. The main difference is that, this time, rather than using hypothetical debt ratios, we estimate IIRs for Brazil using the country's actual external debt-to-GNP ratios for each year from 1979 to 2001. In addition to these estimated IIRs, we report Brazil's actual IIR in the same year as well as the difference between the two. The last two columns show the debt intolerance region within club B in which Brazil actually found itself (based on its external debt and actual IIR, as described in figure 3) and the region in which it would have fallen based on its external debt and the estimated IIR. The shaded area indicates the period when Brazil's external debt was in default or undergoing a restructuring, and the characters in boldface in the last two columns indicate the years in which discrepancies are observed between the actual and the estimated region.

A pattern worth remarking is that Brazil started the estimation period in 1979 with a fairly high IIR, and although its IIR declined thereafter, it remained quite high until the default and restructuring of 1983. Also, the gap between Brazil's actual and its estimated IIR is highest in the run-up to that credit event. According to its actual IIR and external debt ratio, Brazil was in the relatively safe region II on the eve of its 1983 default, whereas according to our estimated IIR it belonged in the most debt-intolerant region (region IV). After the credit event, Brazil remained in the most debt-intolerant region for a few years by both measures. It is noteworthy that, whereas the actual IIR was well above the estimated IIR in the years prior to default, it was below the estimated measure in many of the years when Brazil was in default (though the gap was not large enough to generate a discrepancy between the actual and predicted regions). 
Table 10. Shifting Sands-Transitions Across Debt Intolerance Regions: An Illustration for Brazil

\begin{tabular}{cccccc}
\hline Year & Actual IIR & $\begin{array}{c}\text { Predicted } \\
\text { IIR }\end{array}$ & $\begin{array}{c}\text { Actual } \\
\text { Predicted IIR }\end{array}$ & Actual region & $\begin{array}{c}\text { Predicted } \\
\text { region }\end{array}$ \\
\hline \hline & & & & & I \\
1979 & 64.9 & 36.9 & 27.9 & III \\
1980 & 55.4 & 35.5 & 19.9 & I & III \\
1981 & 49.3 & 35.2 & 14.1 & IV \\
1982 & 51.3 & 34.1 & 17.2 & II & IV \\
1983 & 42.9 & 27.9 & 15.0 & IV & IV \\
1984 & 29.9 & 27.7 & 2.2 & IV & IV \\
1985 & 31.3 & 29.2 & 2.1 & IV & IV \\
1986 & 33.6 & 31.7 & 1.9 & IV & IV \\
1987 & 33.6 & 31.6 & 2.0 & III & III \\
1988 & 28.9 & 33.6 & -4.7 & III & III \\
1989 & 28.5 & 37.8 & -9.4 & III & III \\
1990 & 26.9 & 37.7 & -10.8 & III & III \\
1991 & 26.1 & 36.1 & -10.0 & III & III \\
1992 & 27.1 & 34.7 & -7.6 & III & III \\
1993 & 27.8 & 34.6 & -6.9 & III & III \\
1994 & 29.6 & 36.8 & -7.2 & III & III \\
1995 & 34.2 & 38.9 & -4.8 & III & III \\
1996 & 37.1 & 38.7 & -1.6 & III & IV \\
1997 & 39.2 & 38.1 & 1.0 & IV & IV \\
1998 & 38.4 & 35.8 & 2.6 & IV & III \\
1999 & 37.0 & 29.5 & 7.4 & III & III \\
2000 & 41.8 & 31.4 & 10.4 & III & IV \\
2001 & 42.9 & 28.6 & 14.3 & III & \\
& & & & &
\end{tabular}

Sources: Institutional Investor (various issues) and authors' calculations based on the coefficients from regression (1) in Table 8. Regions are defined in Figure 3 and Table 9. Shaded area denotes years in default or restructuring status; bolded numbers in the last two columns indicate the years where there are differences between the actual and predicted region.

This pattern is also evident in many other episodes in our sample (not shown) and lends support to the view that ratings tend to be procyclical.

\section{Graduating from Debt Intolerance: Some Suggestive Evidence}

As observed above for Brazil, in some years a country’s actual IIR can be considerably higher than the estimated rating obtained from our simple model. On the whole, however, these gaps are neither persistent over time nor systematic in any one direction. Nonetheless, for some countries we do observe consistent, persistent, and sizable positive gaps between the actual and 
the predicted IIR. One interpretation is that these countries either have graduated, or are in the process of graduating, from club B.

To explore the countries in our sample that are plausible graduation candidates, we calculate the difference between the actual and the predicted IIR averaged over the years 1992-2000 - roughly the second half of the estimation period. The five countries with the largest gaps during this period are shown, in descending order, in table 11. Not surprisingly, Greece and Portugal stand out as the most obvious possible cases of graduation from club B to club A. Far back in third and fourth place are Malaysia and Thailand (their 1997-98 crises notwithstanding), both of which have no history of default or high inflation. Chile, the most consistently good performer in Latin America, ranks fifth, suggesting that it may have begun to decouple from its long history of high inflation and adverse credit events.

Table 11. Persistent and sizable under-prediction of creditworthiness (IIR) Evidence of Graduation from Debt Intolerance? 1992-2000 Averages

\begin{tabular}{|c|c|c|c|}
\hline & $\begin{array}{l}\text { Predicted } \\
\text { region }\end{array}$ & Actual region & $\begin{array}{c}\text { Actual IIR minus } \\
\text { predicted IIR }\end{array}$ \\
\hline Greece & IV & II & 41.1 \\
\hline Portugal & IV & II & 35.3 \\
\hline Thailand & IV & II & 22.4 \\
\hline Malaysia & IV & II & 21.2 \\
\hline Chile & IV & II & 19.8 \\
\hline \multicolumn{4}{|l|}{ Memoranda: } \\
\hline Mean of full sample (1992-2000) & & & 6.1 \\
\hline Standard deviation of full sample & & & 12.6 \\
\hline Mean excluding above five countries & & & 2.5 \\
\hline
\end{tabular}

Sources: Institutional Investor (various issues) and authors' calculations based on the coefficients from regression (1) in Table 8. Regions are as defined in Figure 3 and Table 9. 


\section{Ranking Debt Intolerance within Club B}

We have presented evidence supporting the notion that there is a group of countries whose degree of debt intolerance is indeterminate (club B), and that the countries in this group range from relatively "safe" countries (region I) to more precarious countries (regions III and IV) where adverse credit events become increasingly likely. Table 12 presents, for fourteen emerging markets in our core sample, two measures of debt intolerance that allow to assess the relative degree of debt intolerance along a continuum: the average ratio of external debt to GNP over 1979-2000 divided by the average IIR, and the average ratio of external debt to exports divided by the average IIR. Regardless of which of these two summary measures one chooses, those countries with the weakest credit histories register the highest levels of debt intolerance. For example, the group average for the first measure is more than twice as high for countries with a record of past default as for those that have avoided default. The difference between the two groups is much greater, however, when one looks at the measure that uses the debt-toexports ratio as the numerator. These simple summary statistics could therefore be useful to compare the relative degree of debt intolerance across countries (as done here), and over time for any given country. ${ }^{24}$

\footnotetext{
${ }^{24}$ Figure 3 employs the debt-to-output ratio as a metric for dividing club B into regions, but the debt-exports ratio could be used alternatively.
} 
Table 12. Summary Debt Intolerance Measures in Club B Countries: 1979-2000

\begin{tabular}{lcc}
\hline \hline & $\begin{array}{c}(\text { External debt/GNP)/ } \\
\text { Institutional Investor Rating }\end{array}$ & $\begin{array}{c}\text { (External debt/Exports)/ } \\
\text { Institutional Investor Rating }\end{array}$ \\
\hline \hline & Countries with at least one external default or restructuring since 1824 \\
Argentina & 1.1 & 10.6 \\
Brazil & 0.8 & 8.8 \\
Chile & 1.2 & 4.7 \\
Colombia & 0.8 & 4.3 \\
Egypt & 2.1 & 6.7 \\
Mexico & 0.8 & 4.4 \\
Philippines & 1.6 & 5.8 \\
Turkey & 0.9 & 6.0 \\
Venezuela & 1.0 & 3.5 \\
Group average & 1.1 & 6.1 \\
& & \\
& Countries with no external default history \\
India & & \\
Korea & 0.4 & 4.2 \\
Malaysia & 0.5 & 1.4 \\
Singapore & 0.6 & 1.0 \\
Thailand & 0.1 & 0.1 \\
Group average & 0.7 & 2.0 \\
& 0.5 & 1.7 \\
\hline \hline Sours: & & \\
\hline
\end{tabular}

Sources: Authors' calculations based on data from World Bank's, Global Development Finance, and from Institutional Investor. Club B countries as defined in Figure 3 and Table 9.

\section{DEbT SuStainABILITY AND DebT REVERSALS}

Thus far our analysis has focused on quantifying and explaining external debt intolerance. To reiterate, the basic premise is that, because of debt intolerance, some countries periodically have disproportionate difficulty repaying their debts on the original terms, even at levels of indebtedness that would be considered moderate for countries that are not debt intolerant. Here we first discuss the implications of debt intolerance for standard debt sustainability analyses, and then turn our attention to what we call debt reversals - episodes 
during which countries have managed to significantly reduce their external debt relative to GNP. The latter analysis will show that debt-intolerant countries very rarely achieve significant reductions in their debt burden solely through sustained growth or lower interest rates, but instead require some kind of adverse credit event (default or restructuring) to reduce their debt. In addition, the analysis will show that, following such an event, governments in emerging market countries often quickly amass debt once again, and the symptoms of debt intolerance reemerge, often leading to serial default. This evidence will uncover some critical shortcomings of standard sustainability exercises.

Implications of Debt Intolerance for Debt Sustainability Analysis

How does one square our proposed measures of debt intolerance and, more broadly, the existence of debt intolerance with standard approaches to assessing debt sustainability as practiced in both the public and the private sector? Standard debt sustainability analysis, as applied to a country's external debt, works off the following simple accounting relationship: (1) $D(t+1)=[1+r(t)] D(t)-T B(t)$, where $D(t)$ is a country's external debt at time $t, T B$ is its trade balance, and $r$ is the interest rate paid by the country on its external debt. Simple manipulation leads to the following steadystate expression:

(2) $T B / Y=(r-g)(D / Y)$,

where $T B / Y$ is the steady-state ratio of the trade balance to output needed to stabilize the external debt ratio at $D / Y$, and $g$ is the growth rate of output. (A similar calculus applies to deriving sustainable paths for total government debt.) It is well recognized that standard debt sustainability analysis tends to be overly sanguine, in that it does not sufficiently allow for the kinds of real-world shocks that emerging market economies face (including confidence shocks, 
political shocks, terms-of-trade shocks and, not least, shocks to returns in industrial countries).

Efforts have therefore been made to find ways to "stress-test" these sustainability calculations. ${ }^{25}$

Such efforts are useful, but our analysis of debt intolerance suggests that it is also crucial to take other factors into account. First, it is necessary to recognize that the interest rate a country must pay on its debt is an endogenous variable, which depends, among other things, on the country's debt-to-output (or debt-to-exports) ratio. Because the interest rate on debt to private creditors can rise very sharply with the level of debt (the rate charged by official creditors, such as the international financial institutions, typically does not change), a trajectory that may seem marginally sustainable according to standard calculations may in fact be much more problematic when debt intolerance is taken into account (not an uncommon situation, to say the least). This is particularly likely in situations where a country's debt-to-GNP ratio is initially projected to rise in the near future, and only later projected to fall (again, a very common situation).

Second, sustainability analyses need to take into account that a country's initial level of debt (scaled by output or exports) may already exceed, or be close to exceeding, what history suggests is that country's tolerable debt burden. In cases where the initial level of debt or the initial rise in $D / Y$ takes a club B country into a region of extreme debt intolerance (that is, into region IV), conventional sustainability analyses are not likely to be meaningful or useful. Once a country is in the "risk of default" region identified in sovereign debt models and

\footnotetext{
${ }^{25}$ See International Monetary Fund (2002) for a recent discussion of these approaches. As noted, the approaches sometimes focus on total government debt rather than total external debt, but the issues raised here are similar for both. See Williamson (2002) and Goldstein (2003) for recent applications of the standard debt sustainability framework to the case of Brazil.
} 
approximated by our earlier analysis, ${ }^{26}$ there is a risk of both dramatically higher interest rates and a sudden loss of access to market financing. And, as we will see below, the probability that a "virtuous cycle" of falling interest rates and rapid growth will take the country's debt burden back to a safe region is, unfortunately, typically low.

\section{Identifying Debt Reversals}

To identify episodes of large debt reversals for middle- and low-income countries over the period 1970-2000, we select all episodes where the ratio of external debt to GNP fell 25 percentage points or more within any three-year period, and then ascertain whether the decline in this ratio was caused by a fall in the numerator, a rise in the denominator, or some combination of the two. ${ }^{27}$ To exclude cases where the decline in the ratio was primarily driven by changes in the nominal value of dollar GNP, we consider only those episodes where either the decline in the dollar value of external debt was 10 percent or more over the three-year window, or average growth in the three-year period was 5 percent a year or higher. This twostage approach allows us to identify the proximate causes of the debt reversal. If it is a decline in debt, it may be due to either repayment or some type of reduction in the present value of debt (that is, a restructuring); alternatively, if the decline was due to primarily, or solely, to growth, it suggests that the country grew out of its debt.

\footnotetext{
${ }^{26}$ Such models include those of Obstfeld (1994), Velasco (1996), Morris and Shin (2001), and Jahjah and Montiel (2003).

${ }^{27}$ Our basic results appear reasonably robust to our choice of "windows" of 25 percent decline and three yearssee the analysis of Brady plan countries below, however.
} 
We conducted the exercise for both low- and middle-income developing economies. The algorithm yielded a total of fifty-three debt reversal episodes for the period 1970-2000, twenty-six of which occurred in middle-income countries and the rest in low-income countries.

\section{The Debt Reversal Episodes}

Table 13 lists those debt reversal episodes that occurred in middle-income developing countries with populations of at least one million, separating those cases that involved an adverse credit event (a default or a restructuring) from those that did not. ${ }^{28}$ Of the twenty-two debt reversals identified, fifteen coincided with some type of default or restructuring of external debt obligations. In five of the seven episodes that did not coincide with a credit event, the debt reversal was effected primarily through net debt repayments; in only one of these episodes (Swaziland in 1985) did the debt ratio decline strictly because the country grew out of its debt. However, growth was also the principal factor explaining the decline in the debt ratio in four of the fifteen credit event cases (Chile, Morocco, Panama, and the Philippines) and a lesser factor in other seven of those episodes, as well as in four of the episodes that did not coincide with a credit event.. Overall, this exercise shows that growth alone is typically not sufficient to allow countries to substantially reduce their debt burden-yet another reason to be skeptical of overly sanguine standard sustainability calculations for debt-intolerant countries.

\footnotetext{
${ }^{28}$ A similar table summarizing the debt reversals of the low-income countries is available from the authors upon request.
} 
Table 13. Episodes of Declining External Debt, 1970-2000

(Middle-income Countries with a Population of at Least One Million)

\begin{tabular}{|c|c|c|c|c|c|c|c|c|}
\hline \multirow[t]{2}{*}{ Country } & \multirow{2}{*}{$\begin{array}{l}\text { Start of } \\
\text { Episode } \\
\text { (year t) }\end{array}$} & \multicolumn{2}{|c|}{$\begin{array}{c}\text { Debt/GNP } \\
\text { (percent) }\end{array}$} & \multirow{2}{*}{$\begin{array}{l}\text { Cumulative } \\
\text { change in } \\
\text { Total Debt } \\
\text { (US\$ billion) }\end{array}$} & \multirow{2}{*}{$\begin{array}{l}\text { Average real } \\
\text { GDP growth } \\
\text { during episode } \\
\text { (percent) }\end{array}$} & \multirow{2}{*}{$\begin{array}{l}\text { Primary (secondary) } \\
\text { reasons for fall in } \\
\text { Debt/GNP ratio }\end{array}$} & \multirow{2}{*}{\multicolumn{2}{|c|}{$\begin{array}{r}\text { Debt/GNF } \\
\text { end-2000 } \\
\text { (percent) }\end{array}$}} \\
\hline & & $\mathrm{t}$ & $\mathrm{t}+3$ & & & & & \\
\hline \multicolumn{9}{|c|}{ Debt default/restructuring during the episode } \\
\hline Russia & 1999 & 96 & 67 & -14.06 & 5.9 & Debt reduction; (outpu & owth) & 67 \\
\hline Egypt & 1987 & 110 & 79 & -11.13 & 3.4 & Debt reduction; (outpu & owth) & 29 \\
\hline Iran & 1993 & 42 & 16 & -6.80 & 3.1 & Net repayments & & 8 \\
\hline Jordan & 1991 & 249 & 129 & -1.84 & 6.9 & Debt reduction; (outpu & owth) & 99 \\
\hline Bulgaria & 1992 & 116 & 81 & -1.58 & -6.3 & Debt reduction & & 86 \\
\hline Costa Rica & 1987 & 111 & 69 & -0.97 & 4.3 & Debt reduction; (outpu & owth) & 31 \\
\hline Bolivia & 1988 & 113 & 80 & -0.84 & 4.3 & Debt reduction; (outpu & owth) & 72 \\
\hline Chile & 1985 & 142 & 88 & -0.80 & 5.7 & Output growth & & 54 \\
\hline Jamaica & 1990 & 125 & 93 & -0.57 & 2.3 & Debt reduction; (outpu & & 61 \\
\hline Paraguay & 1987 & 69 & 39 & -0.42 & 4.9 & Debt reduction; (outpu & owth) & 41 \\
\hline Gabon & 1978 & 70 & 32 & -0.38 & -8.0 & Net repayments & & 94 \\
\hline Albania & 1992 & 98 & 18 & -0.18 & 2.7 & Debt reduction & & 20 \\
\hline Panama & 1989 & 135 & 100 & 0.03 & 6.8 & Output growth & & 75 \\
\hline Philippines & 1986 & 96 & 68 & 0.45 & 5.2 & Output growth & & 63 \\
\hline Morocco & 1985 & 129 & 98 & 5.01 & 5.6 & Output growth & & 55 \\
\hline \multicolumn{9}{|c|}{ No debt default/restructuring during the episode } \\
\hline Thailand & 1998 & 97 & 66 & -25.24 & 0.1 & Net repayments & & 66 \\
\hline Korea & 1985 & 52 & 20 & -11.42 & 9.7 & Net repayments; (outp & rowth) & 30 \\
\hline Malaysia & 1986 & 83 & 44 & -5.60 & 6.4 & Net repayments; (outp & rowth) & 51 \\
\hline Papua New Guinea & 1992 & 93 & 56 & -1.28 & 8.7 & Net repayments; (outp & rowth) & 71 \\
\hline Lebanon & 1990 & 51 & 17 & -0.43 & 9.1 & Net repayments; (outp & rowth) & 59 \\
\hline Botswana & 1976 & 42 & 16 & -0.03 & 13.5 & Output growth; (net re & ments) & 8 \\
\hline Swaziland & 1985 & 68 & 40 & 0.02 & 9.3 & Output growth & & 17 \\
\hline
\end{tabular}

${ }^{\mathrm{a} /}$ Column lists the economic factors that contributed to at least 20 percent of the decline in the debt-to-GNP ratio during each episode. The contribution of changes in the US dollar value of nominal GNP (which were often sizable) or of changes in the valuation of the debt stock are not listed among the factors.

Sources: World Bank Debt Tables and Global Development Finance (various issues), IMF's World Economic Outlook; Standard \& Poor's (2000); Beim \& Calomiris (2001).

Of those cases involving credit events, Russia and Egypt obtained by far the largest reductions in their nominal debt burden in their restructuring deals: $\$ 14$ billion and $\$ 11$ billion, 
respectively. Two countries involved in the 1997-98 Asian crisis-Thailand and Koreaengineered the largest debt repayments among those episodes where a credit event was avoided.

Conspicuously absent from the large debt reversal episodes shown in table 13 are the well-known Brady restructuring deals of the 1990s. Although our algorithm does place Bulgaria, Costa Rica, Jordan, Nigeria, and Vietnam in the debt reversal category, larger countries such as Brazil, Mexico, and Poland do not register. The reasons for this apparent puzzle are examined below.

\section{The Missing Brady Bunch: Episodes of Rapid Releveraging}

Table 14 traces the evolution of external debt in the seventeen developing countries whose external obligations were restructured under the umbrella of the Brady Plan deals pioneered by Mexico and Costa Rica in the late 1980s. ${ }^{29}$ It is clear from the table why our debt reversal algorithm failed to pick up twelve of these seventeen countries. In ten of those twelve cases, the reason is that the decline in the external debt-to-GNP ratio produced by the Brady restructuring was less than 25 percentage points. But this is only part of the story. Argentina, Nigeria and Peru had higher external debt-to-GNP ratios just three years after their Brady deals than in the year before the restructuring. Moreover, by the end of 2000, seven of the seventeen countries that had undertaken a Brady-type restructuring (Argentina, Brazil, Ecuador, Peru, the Philippines, Poland, and Uruguay) had ratios of external debt to GNP that were higher than they were three years after the Brady deal, and four of those countries (Argentina, Brazil, Ecuador, and Peru) had higher debt ratios by the end of 2000 than just before the Brady deal. By 2002 three members of the Brady bunch had once again defaulted on

\footnotetext{
${ }^{29}$ For details on the Brady debt restructurings of the 1990s, see Cline (1995) and International Monetary Fund (1995). For a survey of the debate prior to the Brady Plan see Williamson (1988).
} 
their external debt (Argentina, Côte d'Ivoire, and Ecuador), and a few others were teetering on the brink. This evidence clearly suggests that, when assessing debt restructuring programs for highly debt-intolerant countries, it is critical to ask whether measures can be taken to reduce the likelihood of the problem remerging in the near term.

Table 14. The Missing Brady Bunch

\begin{tabular}{|c|c|c|c|c|c|c|c|c|}
\hline \multirow[b]{2}{*}{$\begin{array}{l}\text { Country and } \\
\text { year of Brady deal }\end{array}$} & \multicolumn{2}{|c|}{ Year t-1 } & \multirow[b]{2}{*}{$\begin{array}{l}\text { Debt covered } \\
\text { by Brady deal } \\
\text { (billions US\$) }\end{array}$} & \multirow[b]{2}{*}{$\begin{array}{l}\text { Size of debt } \\
\text { reduction } \\
\text { (billions US\$) }\end{array}$} & \multicolumn{2}{|c|}{ Year $\mathrm{t}+3$} & \multicolumn{2}{|c|}{ End of 2000} \\
\hline & $\begin{array}{c}\text { Debt/GNP } \\
\text { (percent) }\end{array}$ & $\begin{array}{c}\text { Total External } \\
\text { Debt } \\
\text { (billions US\$) }\end{array}$ & & & $\begin{array}{c}\text { Debt/GNP } \\
\text { (percent) }\end{array}$ & $\begin{array}{l}\text { Total External } \\
\text { Debt } \\
\text { (billions US\$) }\end{array}$ & $\begin{array}{c}\text { Debt/GDP } \\
\text { (percent) }\end{array}$ & $\begin{array}{l}\text { Total External } \\
\text { Debt } \\
\text { (billions US\$) }\end{array}$ \\
\hline Mexico, 1989 & 56.4 & 99.2 & 48.23 & 6.80 & 31.7 & 112.3 & 26.8 & 150.3 \\
\hline Costa Rica, 1989 & 105.9 & 4.5 & 1.46 & 0.99 & 47.1 & 3.9 & 30.5 & 4.5 \\
\hline Uruguay, 1991 & 49.3 & 4.4 & 1.61 & 0.63 & 31.6 & 5.1 & 42.3 & 8.2 \\
\hline Argentina, 1992 & 35.6 & 65.4 & 19.40 & 2.36 & 39.0 & 98.8 & 52.6 & 146.2 \\
\hline Brazil, 1992 & 30.4 & 121.0 & 40.60 & 4.97 & 23.2 & 160.5 & 41.8 & 238.0 \\
\hline Philippines, 1992 & 71.1 & 32.5 & 4.47 & 1.26 & 49.7 & 37.8 & 63.1 & 50.1 \\
\hline Bulgaria, 1993 & 116.0 & 11.8 & 6.19 & 2.66 & 105.7 & 10.0 & 85.9 & 10.0 \\
\hline Dominican Republic, 1993 & 54.7 & 4.6 & 0.78 & 0.45 & 34.4 & 4.3 & 24.7 & 4.6 \\
\hline Peru, 1997 & 53.3 & 29.0 & 8.50 & 3.90 & 55.0 & 28.6 & 55.0 & 28.6 \\
\hline Côte d'Ivoire, $1998^{\text {a }}$ & 158.1 & 15.6 & 6.90 & 4.40 & 140.9 & 12.1 & 140.9 & 12.1 \\
\hline Vietnam, $1998^{\text {a }}$ & 78.9 & 21.8 & 0.92 & 0.41 & 40.8 & 12.8 & 40.8 & 12.8 \\
\hline
\end{tabular}

Source: IMF (1995) and authors' calculations.

${ }^{a}$ Estimates for year $\mathrm{t}+3$ are those for year 2000 (year $\left.\mathrm{t}+2\right)$.

\section{DOMESTIC DEbT, DOLlarization, AND LibERALIZATION}

Up to this point, our analysis of debt intolerance has focused on a country's total external debt. The reasons for this are twofold. First, until recently, the theoretical literature on public debt in emerging market economies focused primarily on external debt rather than on total government debt. This common practice was grounded in the observation that 
governments in most emerging markets had little scope for financing their fiscal deficits by resorting to the domestic placement of marketable debt. Second, a key point of our empirical analysis has been to show that the external debt burdens that countries are able, and have been able, to tolerate are systematically related to their own credit and inflation histories. We have investigated this proposition using time series for countries' level of external indebtedness dating back to the 1970s. Unfortunately, there is not a sufficient past record to allow a comparable empirical analysis of domestic government debt. That said, an early read of the evidence suggests that a history of external debt intolerance is probably a good predictor of modern-day domestic debt intolerance.

Domestically issued, market-based government debt has become increasingly important for emerging market economies, both as a source of government financing and as a trigger for generalized debt and financial crises. Domestically issued foreign currency debt (the infamous tesobonos) was at the center of the Mexican crisis of December 1994. Such debt also contributed to the costly collapse of the convertibility regime in Argentina in late 2001. And that debt presently accounts for the lion's share of public debt in Brazil and Turkey—and will ultimately determine the fate of those countries' efforts at financial stabilization. Mexico, Argentina, Turkey and Brazil of course, all exhibit high external debt intolerance according to our historical measures.

Recognizing this fact, in this section we discuss some conceptual issues related to the role of domestic government debt in emerging market economies, and we document and explain some related manifestations of debt intolerance — such as dollarization — and offer some explanations for the rapid growth of domestic government debt in recent years. The growth of such debt turns out to be a widespread phenomenon in these economies. We conjecture that, in 
the future, the same historical factors that explain external debt intolerance will extend to domestic debt intolerance, as will the conclusions we have drawn about how rare it is for countries to grow their way out of heavy indebtedness.

There is no easy way to aggregate domestically issued and externally issued government debt for the purpose of assessing financial vulnerability or the likelihood of a debt crisis, and views differ on how to do so. ${ }^{30}$ To be sure, the view that external debt is completely separable from domestically issued debt is dead wrong. As a by-product of capital mobility and financial integration, foreigners hold increasingly large amounts of the domestically issued debt of governments of emerging markets, and their residents increasingly hold instruments issued by governments in advanced economies. Financial integration and open capital accounts encourage active arbitrage across the two markets. In such a setting, a default on domestic government debt can easily trigger a default on foreign debt, first for reputational reasons, and second because induced output and exchange rate effects can easily affect a country's prospects for servicing its foreign debt, not least through the havoc that domestic default wreaks on the banking system.

That said, it is also clearly wrong to assume that domestically issued and foreign-issued debt are perfect substitutes. First, foreigners typically do hold a large share of externally issued debt, whereas domestic residents typically hold most domestically issued debt. Second, the risks of a cutoff of international trade credits and the risks to future international borrowing are undeniably greater following a default on foreign-issued debt. Thus the default calculus simply cannot be the same for the two classes of debt instruments, and they will not, in general, be

\footnotetext{
${ }^{30}$ The recent IMF on debt sustainability (IMF, 2002), for example, proposes to undertake parallel assessments of external and public--domestic and external--debt burdens.
} 
equivalent. (The fundamental distinction between them is clearly reflected in the fact that, at times, rating agencies give the sovereign foreign-issued debt of a country a significantly higher grade than its domestically issued debt.)

Given the lack of theoretical clarity on the distinction between foreign-issued and domestically issued government debt, our objective in this section is to present some basic facts and explore whether the symptoms of debt intolerance seem broadly similar for both types of instrument. We leave it to future research to delineate more clearly the dividing lines between domestic and external debt in a global economy.

The Growth of Domestic Government Debt: New Data

Figure 4 illustrates the rapid growth of marketable domestic government debt in emerging market economies in the late 1990s. By the end of 2001, the stock of domestic government debt of the twenty-four countries represented in the figure amounted to approximately $\$ 800$ billion. More than 25 percent of that stock consisted of debt linked to a foreign currency, and the bulk of the rest was often indexed to some other market variable (for example, as of the end of 2002, about 45 percent of Brazil's domestic government debt was linked to the overnight interest rate). The fraction of domestic government debt that is not indexed to a market variable is typically of very short maturity. Indeed, the successful issuance of nonindexed domestic currency bonds for long-term government financing remains as elusive today for the majority of emerging market economies as it was two or three decades ago. 
Figure 4. Emerging Market Countries: Domestic Government Debt, 1996-2001

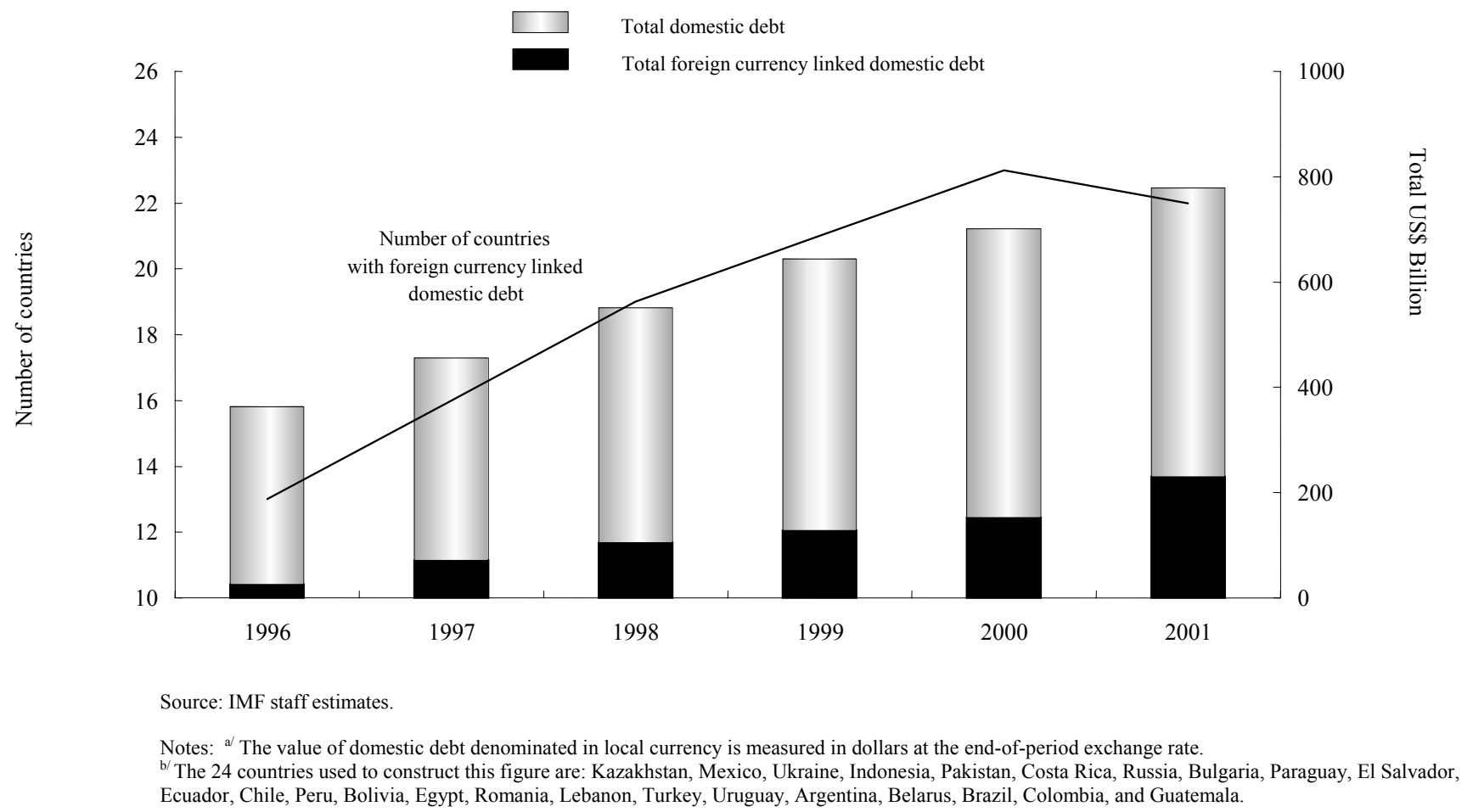

These trends suggest that domestic debt intolerance can manifest itself in a manner similar to external debt intolerance. Indeed, as we will later show for dollarization, many of the variables typically linked to the vulnerability of a country's debt position (maturity structure, indexation, and the like) are manifestations of debt intolerance and may be viewed as linked to a common set of factors.

The surge in domestic government debt is also apparent in the emerging market economies that formed the core sample of our analysis of external debt intolerance. Table 15 shows that the stock of domestic government debt in this group of countries has increased markedly over the last two decades. The rise has been particularly large in the Asian countries - both in those with no default history, and in the Philippines, which has defaulted 
only once in its modern history. But domestic government debt has also risen significantly in a number of Latin American countries, as well as in Turkey.

Table 15. Domestic and External Government Debt in Emerging Market Economies: the 1980s and the 1990s (percent of GDP)

\begin{tabular}{|c|c|c|c|c|c|}
\hline \multicolumn{4}{|c|}{ Early $1980 \mathrm{~s}^{\mathrm{a}}$} & \multicolumn{2}{|c|}{ Late $1990 \mathrm{~s}^{\mathrm{b}}$} \\
\hline $\begin{array}{c}\text { Domestic } \\
d e b t^{c}\end{array}$ & $\begin{array}{c}\text { External } \\
d e b t^{\mathrm{d}}\end{array}$ & $\begin{array}{c}\text { Total } \\
\text { government } \\
\text { debt }\end{array}$ & $\begin{array}{c}\text { Domestic } \\
\text { debt }^{\mathrm{c}}\end{array}$ & $\begin{array}{c}\text { External } \\
\text { debt }^{\mathrm{d}}\end{array}$ & $\begin{array}{c}\text { Total } \\
\text { government } \\
\text { debt }\end{array}$ \\
\hline
\end{tabular}

Countries with at least one external default or restructuring since 1824

$\begin{array}{lrrrrrr}\text { Argentina } & 13.2 & 38.4 & 51.6 & 15.4 & 36.4 & 51.8 \\ \text { Brazil } & 15.9 & 31.4 & 47.3 & 35.8 & 18.5 & 54.3 \\ \text { Chile } & 10.8 & 45.9 & 56.7 & 27.3 & 8.8 & 36.1 \\ \text { Colombia } & 4.4 & 25.8 & 30.2 & 12.4 & 24.5 & 36.9 \\ \text { Mexico } & 2.3 & 37.7 & 40.0 & 9.5 & 26.8 & 36.3 \\ \text { Philippines } & 13.6 & 60.3 & 73.9 & 43.0 & 48.8 & 91.8 \\ \text { Turkey } & 12.9 & 28.8 & 41.7 & 24.4 & 36.5 & 60.9 \\ \text { Venezuela } & 11.6 & 38.5 & 50.1 & 7.4 & 32.6 & 40.0 \\ \text { average } & 10.6 & 38.4 & 48.9 & 21.9 & 29.1 & 51.0\end{array}$

Countries with no history of external default

$\begin{array}{lrrrrrr}\text { India } & 7.1 & 12.3 & 19.4 & 64.9 & 20.6 & 85.5 \\ \text { Korea } & 9.4 & 41.9 & 51.3 & 41.6 & 21.1 & 62.7 \\ \text { Malaysia } & 20.8 & 39.0 & 59.8 & 35.1 & 30.7 & 65.8 \\ \text { Thailand } & 6.1 & 25.2 & 31.3 & 34.6 & 41.5 & 76.1 \\ \text { average } & 10.9 & 29.6 & 40.5 & 44.1 & 28.5 & 72.5\end{array}$

Sources: Government Finance Statistics, World Bank Debt Tables and Global Development Finance, IMF's World Economic Outlook (various issues), IMF estimates and national sources.

a Average for 1980-85, except for domestic debt to GDP ratios in Argentina (1981-1986), Brazil (1981-1985), Mexico (1982-1985) and Turkey (1981-1986.)

${ }^{\mathrm{b}}$ Average for 1996-2000, except for domestic debt to GDP ratio in Korea (1997-2000).

${ }^{c}$ Data for the early 1980s are for general government debt in all countries except Brazil, Chile, Colombia and Mexico for which coverage of the public sector is broader. Data for the late 1990s are for the non-financial public sector.

${ }^{\mathrm{d}}$ External debt of the non-financial public sector as a share of GDP.

In all of the Asian countries in the core sample except India, the buildup of domestic government debt was propelled by the recapitalization of domestic financial systems that 
governments engineered in the aftermath of the 1997-98 crisis. Financial system bailouts also contributed to the rise of domestic government debt in Mexico and Turkey. In the other cases, including India, the buildup of domestic public debt has primarily reflected fiscal profligacy. More precisely, as we will show later, the governments' inability (or unwillingness) to offset the revenue losses stemming from trade and financial reform, and from disinflation, with new taxes or lower spending sets them up for a fall.

Regardless of its origins, and notwithstanding the positive effects that government debt may have for domestic financial markets, the rise of domestic public debt in many emerging market economies arguably overshadows the progress that many of them have made in containing their external debt burden, raising complex questions about their ability to overcome longstanding debt intolerance. Barring a relatively rapid overhaul of their tax and legal systems or determined efforts to reduce their spending, it seems unreasonable to expect that the governments of all these countries will refrain from doing to their domestically issued debt what so many of them in the past have done so often to their external obligations. Indeed, table 15 suggests that a wave of restructuring or outright default on domestic government debts looms large on the horizon for many emerging market economies in the early part of the twenty-first century.

\section{Dollarization as a Manifestation of Debt Intolerance}

The external debts of emerging market economies are, almost without exception, denominated in foreign currency. As shown in the preceding section, however, governments in many emerging markets today also issue domestic debt linked to a foreign currency. Even more countries, including many that have experienced very high or chronic inflation, have highly dollarized banking systems. Table 16 provides a few summary indicators of the degree 
of domestic dollarization in the emerging market economies in our core sample for the period 1996-2001. The last column of the table reports the average value for the period of a composite dollarization index, which ranges from zero when there is no domestic dollarization of any form to a maximum of 20 when the domestic financial system is highly dollarized. ${ }^{31}$

Table 16. Measures of Domestic Dollarization: In Selected Emerging Market Economies 1996-2001

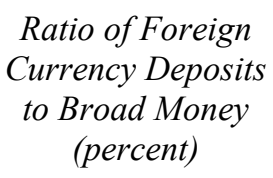

Ratio of Foreign

Currency Deposits

to Broad Money

(percent)

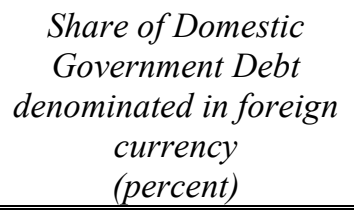

Share of Domestic

Government Debt

denominated in foreign

currency

(percent)

Countries with at least one default or restructuring since 1824

\begin{tabular}{lccc} 
Argentina & 52.5 & 81.8 & 15 \\
Brazil & 0.0 & 19.9 & 2 \\
Chile & 8.3 & 8.4 & 2 \\
Colombia & 0.0 & 6.7 & 1 \\
Egypt & 26.0 & 5.7 & 4 \\
Mexico & 5.5 & 0.0 & 2 \\
Philippines & 27.6 & 0.0 & 3 \\
Turkey & 45.9 & 21.9 & 1 \\
Venezuela & 0.1 & 0.0 & 4.2 \\
Group average & 18.4 & 16.0 & \\
& \multicolumn{1}{c}{ Countries with no default history } \\
India & 0.0 & 0.0 & 0 \\
Korea & 0.0 & 0.0 & 1 \\
Malaysia & 1.8 & 1.7 & 0 \\
Singapore & 0.0 & 0.0 & 0 \\
Thailand & 0.8 & 0.0 & 0.2 \\
Group average & 0.5 & 0.3 & \\
\hline
\end{tabular}

Sources: Reinhart, Rogoff, and Savastano (2003) and sources cited therein.

a/ Index ranges from 0 to 20 , where 20 is the most dollarized.

\footnotetext{
${ }^{31}$ The composite index consists of the sum of the share of foreign currency deposits in broad money and the share of domestic government debt in foreign currency in total domestic debt (both ratios normalized to an index ranging from 0 to 10); see Reinhart, Rogoff, and Savastano (2003) for details.
} 
The table shows considerable variation in the degree of domestic dollarization among countries with a history of default, with Argentina scoring very high on the index but Colombia and Venezuela very low. On the whole, however, countries with a patchier credit history have more domestic dollarization on any of these measures than do countries with no default history. Thus, for example, according to the composite index, countries with a history of external debt default are about four times more dollarized than the most dollarized nondefaulting country (Malaysia). The likely reason is that, by and large, debt-intolerant countries tend to have a history of high (and often chronic) inflation.

We performed a cross-country regression of the domestic dollarization index shown in table 16 against the same independent variables used in the previous section to explain countries' average Institutional Investor ratings (i.e., their long-run creditworthiness), namely, credit and inflation histories and debt-to-output ratios. The results are as follows:

$$
\text { Dollarization Index }{ }_{i}=0.04-2.30 X_{1}+0.08 X_{2}+0.05 X_{3}+0.04 X_{4}
$$

Adjusted $R^{2}=0.31 ; N=62(t$ statistics in parentheses $)$.

In this regression, $X_{1}$ is an intercept dummy for club A countries, $X_{2}$ is the percentage of twelve-month periods since 1948 when inflation in country $i$ was at least 40 percent; $X_{3}$ is the percentage of years since 1824 during which the country was in default or restructuring its debt; and $X_{4}$ is the external debt-to-GNP ratio. Considering that dollarization is a form of indexation, it is not surprising that a country's inflation history is the most important variable in explaining it. The external debt-to-GNP ratio is also significant and has a positive coefficient. Although the interpretation of the role of external debt is less obvious, a reasonable conjecture is that, when the external debt burden is high, governments are more likely to resort to inflationary 
financing of their fiscal imbalances and, in the process, to suffocate the development of a market for nominal government debt in domestic currency. Indeed, this has clearly happened in many of the highly dollarized economies.

\section{Liberalization, Stabilization, and Its Consequences for Debt}

Many factors contributed to the alarming rise in domestic government debt reported in table 15. Key among these have been the revenue losses from the wide-ranging liberalizations undertaken by emerging markets since the late 1980s. The last column of table 17 shows that trade liberalization typically entailed revenue losses for the emerging markets in our core sample. A similar pattern is discernible in figure 5. The left-hand panel shows a steady decline in trade tax revenue as a share of GDP in four countries from our core sample during that period. In some cases this revenue loss was offset by higher revenue from other sources (such as value added taxes). However, the estimates in table 17 show that, for the group as a whole, total tax revenue as a share of GDP also experienced a cumulative decline over the last two decades.

Declining trade taxes were not the only cause of erosion of the traditional sources of revenue in emerging market economies. In the wake of financial liberalization, revenue from financial repression also vanished, as table 18 shows. Interest rate ceilings were lifted, and bank loans to the government at subsidized interest rates gave way to market-based domestic public debt at high interest rates. As presciently noted by Ronald McKinnon in the early 1990s (see footnote 5), the outcome was often a significant increase in domestic interest outlays by the government, a trend that is clearly captured in the right-hand panels of figure 5 and in table 17 (for countries with a history of default). Simply put, much of the debt that governments had for 
Table 17. The Dark Side of Disinflation and Liberalization: Changes in the fiscal accounts 1980-2000 (Average changes for the group as a percent of GDP)

\begin{tabular}{|c|c|c|c|c|}
\hline & $\begin{array}{c}\text { Change } \\
\text { from 1980-85 } \\
\text { to } 1986-1990\end{array}$ & $\begin{array}{c}\text { Change } \\
\text { from 1986-90 } \\
\text { to 1991-1995 }\end{array}$ & $\begin{array}{c}\text { Change } \\
\text { from 1990-95 } \\
\text { to 1996-2000 }\end{array}$ & $\begin{array}{c}\text { Cumulative change } \\
\text { from 1980-85 } \\
\text { to } 1996-2000\end{array}$ \\
\hline \multicolumn{5}{|c|}{ Countries with at least one default or restructuring since $1824^{\mathrm{a}}$} \\
\hline Central government expenditures & -1.0 & -0.7 & 0.4 & -1.3 \\
\hline Interest payments & 3.4 & -1.1 & -0.5 & 1.8 \\
\hline Central government revenues & -2.9 & 1.7 & 0.0 & -1.2 \\
\hline Tax revenues & -2.0 & 1.0 & 0.5 & -0.5 \\
\hline Trade taxes & -0.3 & -0.2 & -0.4 & -0.9 \\
\hline Central government deficit & 2.4 & -2.3 & 0.5 & 0.6 \\
\hline Seigniorage revenues & -0.8 & -0.3 & -1.2 & -2.3 \\
\hline \multicolumn{5}{|c|}{ Countries with no history of default ${ }^{\mathrm{b}}$} \\
\hline Central government expenditures & -1.2 & -2.7 & 0.5 & -3.4 \\
\hline Interest payments & 0.8 & -1.2 & -0.6 & -1.0 \\
\hline Central government revenues & 0.7 & 0.5 & 0.5 & 1.7 \\
\hline Tax revenues & -1.2 & 0.8 & -0.7 & -1.1 \\
\hline Trade taxes & -0.5 & -0.6 & -0.5 & -1.6 \\
\hline Central government deficit & -1.8 & -3.2 & 0.0 & -5.0 \\
\hline Seigniorage revenues & 0.5 & 0.3 & -0.8 & 0.0 \\
\hline
\end{tabular}

\footnotetext{
${ }^{a}$ Argentina, Brazil, Chile, Colombia, Egypt, Mexico, Philippines, Turkey, and Venezuela.

${ }^{\mathrm{b}}$ India, Korea, Malaysia, Singapore, and Thailand.

Source: Appendix Table D.5.
} 
Figure 5. Vanishing Taxes and Rising Debt Servicing Costs (Percent of GDP, three-year moving average)
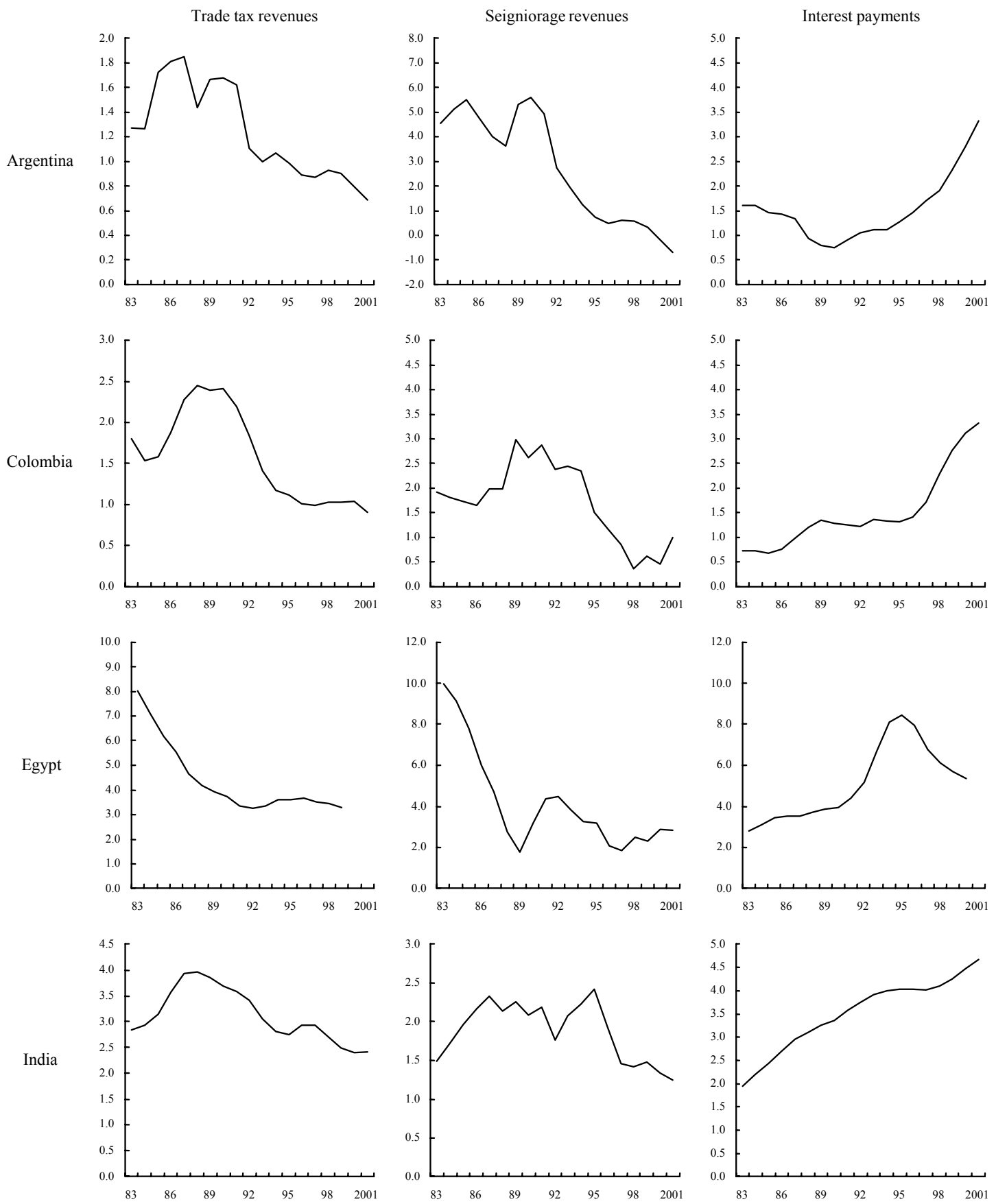

Sources: International Monetary Fund,International Financial Statistics and Government Finance Statistics 
Table 18. Revenues from Financial Repression: Early-1980s and late-1990s (in percent of GDP)

\begin{tabular}{cccc}
\hline & Early 1980s $\mathrm{s}^{\mathrm{a}}$ & & \multicolumn{2}{c}{ Late 1990s ${ }^{\mathrm{b}}$} \\
\cline { 2 - 4 } & Measure 2 & Measure 3 & Measure 2 Measure 3
\end{tabular}

Countries with at least one external default or restructuring since 1824

$\begin{array}{lllrrr}\text { Argentina } & \text { n.a. } & 0.0 & 2.1 & -0.6 & -1.6 \\ \text { Brazil } & 0.5 & \text { n.a. } & \text { n.a. } & -4.5 & -3.6 \\ \text { Chile } & \text { n.a. } & 0.4 & -1.6 & -1.7 & -1.7 \\ \text { Colombia } & 0.3 & -0.3 & -0.2 & -0.6 & -0.7 \\ \text { Mexico } & 5.8 & 2.0 & 1.5 & -0.4 & -0.2 \\ \text { Philippines } & 0.8 & \text { n.a. } & \text { n.a. } & -2.7 & -0.8 \\ \text { Turkey } & 2.7 & \text { n.a. } & \text { n.a. } & 0.4 & 0.5\end{array}$

Countries with no history of external default

$\begin{array}{lccccc}\text { Thailand } & 0.8 & -0.6 & -2.5 & -1.4 & -2.1 \\ \text { India } & 2.9 & \text { n.a. } & \text { n.a. } & -0.6 & -0.5 \\ \text { Korea } & 0.6 & \text { n.a. } & \text { n.a. } & -1.9 & -2.1 \\ \text { Malaysia } & 1.0 & \text { n.a. } & \text { n.a. } & -0.7 & -2.3\end{array}$

\footnotetext{
${ }^{a}$ Average for 1980-1985, except for Measure 1 estimates for Brazil (1983-1987), Malaysia (1979-1981) and Mexico (1984-1987.)

${ }^{\mathrm{b}}$ Average for 1996-2000; except for Korea, Thailand, and Malaysia where averages are for 1997-2000.

Notes: An n.a. stands for not available.

Measure 1: Estimates from measure proposed by Giovannini and de Melo (1993). Revenue is calculated as the difference between the foreign and the domestic effective interest rate multiplied by the ratio of government domestic debt to GDP.

Measure 2: Estimates from measure proposed by Easterly (1989). Revenue is calculated as the negative of the domestic real interest rate multiplied by the ratio of government domestic debt in domestic currency to GDP. Measure 3: Estimates from measure proposed by Easterly and Schmidt-Hebbel (1994). Revenue is calculated as the difference between the OECD average real interest rate and the domestic real interest rate multiplied by the ratio of bank deposits in domestic currency to GDP.
}

long crammed down the throats of financial intermediaries at below-market interest rates suddenly became part of those governments' market debt burden. Debt intolerance symptoms rose accordingly.

In addition to revenue losses and higher debt servicing costs, many of the emerging market economies in our core sample — particularly the group with a default history—had traditionally relied on revenue from seigniorage to finance a nontrivial fraction of their fiscal 
deficits. As those countries succeeded in reducing inflation, revenue from seigniorage became much less important. As table 17 shows, the cumulative decline was over 2 percent of GDP, and for some countries (such as Argentina and Egypt, as shown in the middle panels of figure 5) the decline was even greater. All in all, for those governments that did not manage to bring expenditure in line with the new realities, one outcome of liberalization and inflation stabilization has been a heavier reliance on domestic or foreign debt financing, or both.

\section{Reflections on Policies for DebT-InTOLERANT COUNTRIES}

The sad fact that our analysis reveals is that once a country slips into being a serial defaulter, it retains a high level of debt intolerance that is difficult to shed. Countries can and do graduate to greater creditworthiness, but the process is seldom fast or easy. Absent the pull of an outside political anchor, such as the European Union or, one hopes, the North American Free Trade Agreement for Mexico, recovery may take decades or even centuries. The implications are certainly sobering for sustainability exercises that ignore debt intolerance, and even for debt restructuring plans that pretend to cure the problem permanently, simply through a one-time reduction in the face value of a country's debt.

How serious are the consequences of debt intolerance? Is a country with weak internal structures that make it intolerant to debt doomed to follow a trajectory of slower growth and higher macroeconomic volatility? At some level, the answer has to be yes, but constrained access to international capital markets is best viewed as a symptom, not a cause, of the disease.

Rather, the institutional failings that make a country intolerant to debt pose the real impediment. The basic problem is threefold. First, the modern empirical growth literature increasingly points to "soft" factors, such as institutions, corruption, and governance, as far 
more important than differences in capital-labor ratios in explaining cross-country differences in income per capita. Simply equalizing the marginal product of physical capital across countries (the sine qua non of capital market integration in a deterministic world) only goes a limited way toward equalizing marginal labor products. ${ }^{32}$ Second, quantitative methods have similarly suggested that the risk-sharing benefits of capital market integration (that is, the lowering of consumption volatility as opposed to the acceleration of consumption growth) may also be relatively modest. Moreover, these results pertain to an idealized world where one does not have to worry about gratuitous, policy-induced macroeconomic instability, poor domestic bank regulation, corruption, and (not least) policies that distort capital inflows toward shortterm debt. ${ }^{33}$ Third, there is evidence to suggest that capital flows to emerging markets are markedly procyclical, and that this may make macroeconomic policies in these countries procyclical as well, as, for instance, when capital outflows force a tightening of fiscal policy and the raising of interest rates. ${ }^{34}$ Arguably, more limited, but also more stable, access to capital markets may do more to improve welfare than the boom-bust pattern so often observed in the past. The deeply entrenched idea that an emerging market economy's growth trajectory will be hampered by limited access to debt markets is no longer as compelling as was once thought.

\footnotetext{
${ }^{32}$ For a broader discussion, see International Monetary Fund (2003, chapter 3).

${ }^{33}$ Prasad and others (2003) find that, during the 1990s, economies whose financial sectors were de facto relatively open experienced, on average, a rise in consumption volatility relative to output volatility, contrary to the premise the capital market integration spreads country-specific output risk. The same authors also argue that the crosscountry empirical evidence on the effects of capital market integration on growth shows only weak positive effects at best, and arguably none.

${ }^{34}$ See Kaminsky, Reinhart, and Végh (2003) on this issue.
} 
The modern empirical growth literature does not actually paint sharp distinctions between different types of capital flows, whether it be debt versus equity, portfolio versus direct investments, or long-term versus short-term. Practical policymakers, of course, are justifiably quite concerned with the form that cross-border flows take. For example, foreign direct investment (FDI) is generally thought to have properties that make it preferable to debt: it is less volatile, it is often associated with technology transfer, and so on. ${ }^{35}$ We generally share the view that FDI and other forms of equity investment are somewhat less problematic than debt, but one wants to avoid overstating the case. In practice, the three main types of capital inflows -FDI, portfolio equity, and loans — are often interlinked: for example, foreign firms often bring cash into a country in advance of building or acquiring plant facilities. Moreover, derivative contracts often blur the three categories, and even the most diligent statistical authorities can find it hard to distinguish accurately among different types of foreign capital inflows (not to mention that, when in doubt, some countries prefer to label a given investment as FDI, to lower their apparent vulnerability). Even with these qualifications, however, we believe that governments in advanced economies can do more to discourage emerging market economies from excessive dependence on risky nonindexed debt relative to other forms of capital flows. ${ }^{36}$

\footnotetext{
${ }^{35}$ Of course, it was not always so. Before the 1980 s, many governments viewed allowing FDI as equivalent to mortgaging their countries' future, and therefore preferred borrowing in order to retain full ownership of the country's assets. And, of course, where FDI was more dominant (for example, in investment in oil and other natural resources in the 1950s and 1960s), pressure for nationalization increased. Thus FDI should not be regarded as a panacea for poor growth performance.

${ }^{36}$ Rogoff (1999) and Bulow and Rogoff (1990) argue that creditor countries' legal systems should be amended so that they no longer tilt capital flows toward debt.
} 
Lastly, short-term debt, although typically identified as the main culprit in precipitating debt crises, also helps facilitate trade in goods and is necessary in some measure to allow private agents to execute hedging strategies. Of course, one would imagine that most of the essential benefits to having access to capital markets could be enjoyed with relatively modest debt-to-GNP ratios.

All in all, debt intolerance need not be fatal to growth and macroeconomic stability. However, the evidence presented here suggests that, to overcome debt intolerance, policymakers need to be prepared to keep debt levels - especially government debt levels-low for extended periods while undertaking more basic structural reforms to ensure that the country can eventually digest a heavier debt burden. This applies not only to external debt but also to the very immediate and growing problem of domestic government debt. Policymakers who face tremendous short-term pressures will still choose to engage in high-risk borrowing, and, at the right price, markets will let them. But an understanding of the basic problem, at least, should guide the citizens of such countries, not to mention the international lending institutions and the broader international community, in making their own decisions.

In our view, developing a better understanding of the problem of serial default on external debt obligations is essential to designing better domestic and international economic policies aimed at crisis prevention and resolution. As we have shown, debt intolerance can be captured systematically by a relatively small number of variables, principally a country's own history of default and high inflation. Debt-intolerant countries face surprisingly low thresholds for external borrowing, beyond which the risks of default or restructuring become significant. With the recent explosion of domestic borrowing, as documented by the new data presented in this paper, these thresholds for external debt are now clearly even lower, although it remains an 
open question to what extent domestic and external debt can be aggregated for purposes of analysis. This question needs urgently to be addressed, in part because many questions involving bailouts by the international community surround it. Our initial results suggest that the same factors that determine external debt intolerance (not to mention other manifestations of debt intolerance, such as dollarization) are also likely to impinge heavily on domestic debt intolerance. We have also shown that whereas debt-intolerant countries need badly to find ways to bring their debt-GNP ratios down to safer ground, doing so is not easy. Historically, those countries that have escaped high external debt-GNP ratios, through rapid growth or through sizable repayments over many years, are very much the exception. Most large reductions in the external debt of emerging markets have instead been achieved primarily through restructuring or default. The challenge today is to find ways other than still more debt to channel capital to debt-intolerant countries, to prevent the cycle from repeating itself for yet another century to come.

\section{Conclusions}

Cycles in capital flows to emerging markets have now been with us for nearly two hundred years. Some of the players, both borrowers and lenders, may change but the patterns the cycles follow have remained singularly similar over time. When interest rates are low, when liquidity is ample, and when the prospects for equity markets dim in the world's financial centers, investors will seek higher returns elsewhere. During these periods, it is easier for governments in emerging markets to borrow from abroad - and borrow they do. But history has shown that for many of these countries, to borrow is to brook default. As the track record of serial default highlights, many of these booms ended in tears. The policy challenge for these 
countries is to address a chronic long term problem - their own debt intolerance - not to take remedial measures that allow them to gain the favor of international capital markets for a few of months, or even years.

This paper has taken a first step toward making the concept of debt intolerance operational. We have conjectured that, beyond reputational factors, serial default may owe to a vicious cycle in which default weakens a country's institutions in turn making subsequent defaults more likely. We also have stressed that safe debt thresholds vary from country to country and depend importantly on history. Clearly, much more research is needed to shed light on what other factors (economic, political, and institutional) figure in the calculus of what debt levels, external and domestic, are sustainable, and what are the true long-term costs of default. 


\section{APPENDIX A}

\section{Definitions}

External debt: the total liabilities of a country with foreign creditors, both official (public) and private. Creditors often determine all the terms of the debt contracts, which are normally subject to the jurisdiction of the foreign creditors or, for multilateral credits, to international law.

Total government (or public) debt: the total debt liabilities of a government with both domestic and foreign creditors, where "government" normally comprises the central administration, provincial and local governments, and all entities that borrow with an explicit government guarantee.

Government domestic debt: all debt liabilities of a government that are issued underand subject to - national jurisdiction, regardless of the nationality of the creditor. Terms of the debt contracts may be market determined or set unilaterally by the government.

Government foreign currency domestic debt: debt liabilities of a government that are issued under national jurisdiction but expressed in (or linked to) a currency different from the national currency. 


\section{APPENDIX B}

\section{Sample Description}

To illustrate the extent to which modern-day debt intolerance arises from countries' own external credit histories (because of persistence in certain economic and social characteristics as well as reputational factors), we use throughout the paper a core sample comprising three groups of countries: emerging market economies with a history of default or restructuring of external debt, emerging market economies without a history of default or restructuring, and advanced economies, which mostly have no history of default except during wartime (for instance, in the case of Japan and Italy during World War II). Included in the first group are countries with a history of default or restructuring that involved concessional terms: Argentina, Brazil, Chile, Colombia, Egypt, Mexico, the Philippines, Turkey, and Venezuela. Both of the other two groups consist of countries that have no history of external debt default or restructuring, but we consider it important to distinguish developing from advanced economies. Emerging market economies with an unblemished credit record belong to a different debtor "club" from their more advanced counterparts. The core emerging market economies with no history of default are India, Korea, Malaysia, Singapore, and Thailand. The core sample of advanced industrial countries consists of Australia, Canada, Italy, New Zealand, Norway, and the United States.

Appendix table B1 provides a complete list of the countries used in the empirical analysis and their individual Institutional Investor ratings averaged across 1979-2002. 
Appendix Table B1. Countries in the Sample and Average Institutional Investor Ratings 1979-2002

\begin{tabular}{|c|c|c|c|}
\hline Country & $\begin{array}{l}\text { Average Institutional } \\
\text { Investor Rating }\end{array}$ & Country & $\begin{array}{l}\text { Average Institutional } \\
\text { Investor Rating }\end{array}$ \\
\hline \multicolumn{4}{|c|}{ Club A: Institutional Investor ratings 67.7 and above } \\
\hline United States & 92.8 & Finland & 77.2 \\
\hline Japan & 92.5 & Denmark & 76.9 \\
\hline Canada & 86.0 & Italy & 76.4 \\
\hline Norway & 84.3 & Spain & 73.8 \\
\hline Singapore & 79.9 & Ireland & 71.4 \\
\hline Sweden & 79.7 & New Zealand & 70.7 \\
\hline Australia & 77.3 & Hong Kong & 68.0 \\
\hline \multicolumn{4}{|c|}{ Club B: $67.7<$ Institutional Investor ratings $<24.1$} \\
\hline Malaysia & 63.5 & Turkey & 34.9 \\
\hline South Korea & 63.4 & Philippines & 34.7 \\
\hline Portugal & 63.3 & Argentina & 34.7 \\
\hline Saudi Arabia & 62.8 & Morocco & 34.6 \\
\hline Thailand & 55.7 & Jordan & 34.0 \\
\hline Greece & 54.5 & Egypt & 33.7 \\
\hline Czech Republic & 54.5 & Paraguay & 32.7 \\
\hline Hungary & 50.5 & Panama & 32.5 \\
\hline Chile & 47.5 & Poland & 32.2 \\
\hline India & 46.5 & Romania & 31.4 \\
\hline South Africa & 46.8 & Kenya & 29.2 \\
\hline Indonesia & 46.0 & Costa Rica & 28.3 \\
\hline Mexico & 45.8 & Sri Lanka & 28.2 \\
\hline Colombia & 44.6 & Ecuador & 27.7 \\
\hline Israel & 42.8 & Nigeria & 26.0 \\
\hline Venezuela & 41.5 & Peru & 25.9 \\
\hline Algeria & 39.2 & Pakistan & 25.7 \\
\hline Ghana & 37.6 & Swaziland & 25.4 \\
\hline Brazil & 37.4 & Zimbabwe & 24.9 \\
\hline Uruguay & 37.1 & Nepal & 24.5 \\
\hline Papua New Guinea & 35.5 & & \\
\hline \multicolumn{4}{|c|}{ Club C: Institutional Investor ratings 24.1 and below } \\
\hline Dominican Republic & 22.7 & & \\
\hline Jamaica & 21.5 & & \\
\hline Bolivia & 19.0 & & \\
\hline El Salvador & 18.0 & & \\
\hline Mali & 16.6 & & \\
\hline Tanzania & 14.7 & & \\
\hline Ethiopia & 11.5 & & \\
\hline
\end{tabular}

Source: Institutional Investor, various issues. 


\section{APPENDIX C}

Table C1. Data Sources

\begin{tabular}{|c|c|c|}
\hline Series & Description and sources & Sample period \\
\hline $\begin{array}{l}\text { Institutional Investor's } \\
\text { Country Credit Ratings }\end{array}$ & Institutional Investor, various issues. & 1979-2002 \\
\hline $\begin{array}{l}\text { Secondary market prices of } \\
\text { debt }\end{array}$ & $\begin{array}{l}\text { Salomon Brothers, Inc., ANZ Bank } \\
\text { Secondary Market Price Report. }\end{array}$ & 1986-1992 \\
\hline EMBI spread & JP Morgan Chase, & 1992-2002 \\
\hline External debt/GNP & World Bank, Global Development Finance & $1970-2000$ \\
\hline External debt/exports & World Bank, Global Development Finance & $1970-2000$ \\
\hline $\begin{array}{l}\text { Interest payments on external } \\
\text { debt }\end{array}$ & World Bank, Global Development Finance & $1970-2000$ \\
\hline $\begin{array}{l}\text { General government } \\
\text { debt/GNP (OECD countries) }\end{array}$ & OECD data & $1970-2002$ \\
\hline $\begin{array}{l}\text { General government } \\
\text { debt/exports (OECD } \\
\text { countries) }\end{array}$ & OECD data & $1970-2002$ \\
\hline Domestic government debt & $\begin{array}{l}\text { International Monetary Fund, Government } \\
\text { Fiscal Statistics; IMF staff estimates. }\end{array}$ & $\begin{array}{l}1980-1986 \\
1996-2001\end{array}$ \\
\hline $\begin{array}{l}\text { Probability of inflation above } \\
40 \text { percent }\end{array}$ & $\begin{array}{l}\text { International Monetary Fund, International } \\
\text { Financial Statistics and Reinhart and } \\
\text { Rogoff (2002). }\end{array}$ & $1958-2001$ \\
\hline $\begin{array}{l}\text { Probability of being in a state } \\
\text { of default or restructuring }\end{array}$ & $\begin{array}{l}\text { Beim and Calomiris (2001), Standard and } \\
\text { Poor's Credit Week (various issues), } \\
\text { Reinhart (2002) and authors' calculations. }\end{array}$ & 1824-1999 \\
\hline Domestic dollarization index & Reinhart, Rogoff, and Savastano (2003). & $1996-2001$ \\
\hline $\begin{array}{l}\text { Ratio of foreign currency } \\
\text { deposits to broad money }\end{array}$ & $\begin{array}{l}\text { International Monetary Fund, International } \\
\text { Financial Statistics and various central } \\
\text { banks. }\end{array}$ & $1996-2001$ \\
\hline $\begin{array}{l}\text { Share of domestic } \\
\text { government debt } \\
\text { denominated in foreign } \\
\text { currency }\end{array}$ & IMF Staff estimates. & $1996-2001$ \\
\hline $\begin{array}{l}\text { Central government } \\
\text { expenditures/GDP }\end{array}$ & $\begin{array}{l}\text { International Monetary Fund, Government } \\
\text { Finance Statistics }\end{array}$ & $1980-2000$ \\
\hline Interest payments/GDP & $\begin{array}{l}\text { International Monetary Fund, Government } \\
\text { Finance Statistics }\end{array}$ & $1980-2000$ \\
\hline $\begin{array}{l}\text { Central government revenues/ } \\
\text { GDP }\end{array}$ & $\begin{array}{l}\text { International Monetary Fund, Government } \\
\text { Finance Statistics }\end{array}$ & $1980-2000$ \\
\hline Tax revenues/GDP & $\begin{array}{l}\text { International Monetary Fund, Government } \\
\text { Finance Statistics }\end{array}$ & $1980-2000$ \\
\hline Trade taxes/GDP & $\begin{array}{l}\text { International Monetary Fund, Government } \\
\text { Finance Statistics }\end{array}$ & $1980-2000$ \\
\hline Seigniorage/GDP & $\begin{array}{l}\text { International Monetary Fund, International } \\
\text { Financial Statistics, authors' calculations }\end{array}$ & $1980-2000$ \\
\hline
\end{tabular}




\section{APPENDIX D}

Table D.1. Coefficient of Year Dummy in Panel Regressions: Fixed Effects Pooled Least Squares (Emerging Market Countries Only, 1979-2000)

\begin{tabular}{|c|c|c|c|c|}
\hline \multirow[b]{2}{*}{ Variable } & \multicolumn{4}{|c|}{ Dependent Variable: Institutional Investor Rating } \\
\hline & Coefficient & Stnd. Error & t-Statistic & Probability \\
\hline Debt/GNP & -0.13 & 0.01 & -9.93 & 0.00 \\
\hline 1980 & -1.59 & 1.78 & -0.90 & 0.37 \\
\hline 1981 & -2.31 & 1.76 & -1.31 & 0.19 \\
\hline 1982 & -5.17 & 1.77 & -2.92 & 0.00 \\
\hline 1983 & -9.39 & 1.77 & -5.32 & 0.00 \\
\hline 1984 & -12.60 & 1.77 & -7.11 & 0.00 \\
\hline 1985 & -12.32 & 1.78 & -6.91 & 0.00 \\
\hline 1986 & -11.91 & 1.79 & -6.65 & 0.00 \\
\hline 1987 & -12.23 & 1.78 & -6.84 & 0.00 \\
\hline 1988 & -12.74 & 1.78 & -7.15 & 0.00 \\
\hline 1989 & -12.69 & 1.78 & -7.12 & 0.00 \\
\hline 1990 & -13.17 & 1.77 & -7.46 & 0.00 \\
\hline 1991 & -13.19 & 1.77 & -7.47 & 0.00 \\
\hline 1992 & -13.48 & 1.74 & -7.76 & 0.00 \\
\hline 1993 & -11.78 & 1.74 & -6.79 & 0.00 \\
\hline 1994 & -9.97 & 1.72 & -5.79 & 0.00 \\
\hline 1995 & -8.53 & 1.72 & -4.97 & 0.00 \\
\hline 1996 & -7.85 & 1.71 & -4.58 & 0.00 \\
\hline 1997 & -6.56 & 1.71 & -3.83 & 0.00 \\
\hline 1998 & -5.94 & 1.72 & -3.45 & 0.00 \\
\hline 1999 & -6.64 & 1.72 & -3.86 & 0.00 \\
\hline 2000 & -4.26 & 1.72 & -2.48 & 0.01 \\
\hline
\end{tabular}


Table D.2. Country-Specific Fixed Effects Coefficients (Emerging Market Countries Only, 1979-2000)

\begin{tabular}{ll} 
Malaysia & 79.18 \\
Portugal & 77.24 \\
Korea & 76.19 \\
Saudi Arabia & 72.04 \\
Greece & 70.81 \\
Thailand & 70.81 \\
Czech Rep. & 68.79 \\
Hungary & 65.91 \\
Indonesia & 64.78 \\
Chile & 63.11 \\
Israel & 60.18 \\
Mexico & 59.23 \\
Colombia & 58.48 \\
India & 57.89 \\
Venezuela & 57.67 \\
South Africa & 54.86 \\
Poland & 53.98 \\
Morocco & 52.42 \\
Egypt & 51.95 \\
Jordan & 56.38 \\
Panama & 51.82 \\
Philippines & 51.06 \\
Brazil & 50.26 \\
Uruguay & 50.17 \\
Argentina & 49.89 \\
Turkey & 48.47 \\
Costa Rica & 45.04 \\
Ghana & 48.45 \\
Ecuador & 48.15 \\
Nigeria & 47.56 \\
Kenya & 47.52 \\
Paraguay & 46.42 \\
Sri Lanka & 45.64 \\
Peru & 42.20 \\
Romania & 41.68 \\
Pakistan & 40.89 \\
Zimbabwe & 40.32 \\
& \\
\hline
\end{tabular}


Table D.3 Coefficients on Year dummy, Panel Regressions, full sample, 1979-2000

\begin{tabular}{|c|c|c|c|c|}
\hline \multirow[b]{2}{*}{ Variable } & \multicolumn{2}{|c|}{ Dependent Variable: } & \multicolumn{2}{|c|}{ Institutional Investor Rating } \\
\hline & cient & Std. Error & $t$-Statistic & Probability. \\
\hline Debt/GNP Club A & -0.00 & 0.03 & 0.20 & 0.85 \\
\hline Debt/GNP Non-Club A & -0.10 & 0.01 & -8.79 & 0.00 \\
\hline 1980 & -1.76 & 1.51 & -1.17 & 0.24 \\
\hline 1981 & -3.10 & 1.49 & -2.08 & 0.04 \\
\hline 1982 & -5.96 & 1.49 & -3.99 & 0.00 \\
\hline 1983 & -10.10 & 1.48 & -6.81 & 0.00 \\
\hline 1984 & -12.77 & 1.48 & -8.64 & 0.00 \\
\hline 1985 & -12.60 & 1.48 & -8.49 & 0.00 \\
\hline 1986 & -12.16 & 1.49 & -8.16 & 0.00 \\
\hline 1987 & -12.59 & 1.49 & -8.47 & 0.00 \\
\hline 1988 & -13.02 & 1.48 & -8.77 & 0.00 \\
\hline 1989 & -12.91 & 1.48 & -8.74 & 0.00 \\
\hline 1990 & -12.98 & 1.47 & -8.83 & 0.00 \\
\hline 1991 & -13.08 & 1.47 & -8.92 & 0.00 \\
\hline 1992 & -13.10 & 1.46 & -9.00 & 0.00 \\
\hline 1993 & -11.60 & 1.46 & -7.95 & 0.00 \\
\hline 1994 & -9.76 & 1.46 & -6.71 & 0.00 \\
\hline 1995 & -8.47 & 1.45 & -5.83 & 0.00 \\
\hline 1996 & -7.70 & 1.45 & -5.31 & 0.00 \\
\hline 1997 & -6.41 & 1.44 & -4.46 & 0.00 \\
\hline 1998 & -5.72 & 1.44 & -3.96 & 0.00 \\
\hline 1999 & -5.92 & 1.44 & -4.10 & 0.00 \\
\hline 2000 & -3.32 & 1.44 & -2.30 & 0.02 \\
\hline
\end{tabular}


Table D.4. Country-specific Fixed Effects Coefficients in Panel Regressions (All Countries, 1979-2000)

\begin{tabular}{|c|c|}
\hline$\overline{J a p a n}$ & 101.70 \\
\hline United States & 101.50 \\
\hline Canada & 94.32 \\
\hline Norway & 92.29 \\
\hline Singapore & 90.87 \\
\hline Denmark & 87.48 \\
\hline Finland & 86.61 \\
\hline Italy & 84.16 \\
\hline Australia & 80.68 \\
\hline Ireland & 79.56 \\
\hline Malaysia & 77.74 \\
\hline Korea & 75.31 \\
\hline Saudi Arabia & 72.07 \\
\hline Portugal & 70.16 \\
\hline Thailand & 69.49 \\
\hline Czech Rep. & 67.42 \\
\hline Hungary & 64.11 \\
\hline Indonesia & 62.98 \\
\hline Greece & 61.32 \\
\hline Chile & 61.18 \\
\hline Mexico & 57.94 \\
\hline Colombia & 57.44 \\
\hline India & 57.29 \\
\hline Venezuela & 56.17 \\
\hline South Africa & 53.99 \\
\hline Jordan & 53.15 \\
\hline Poland & 52.26 \\
\hline Israel & 50.26 \\
\hline Morocco & 50.11 \\
\hline Egypt & 49.50 \\
\hline Brazil & 49.26 \\
\hline Philippines & 49.15 \\
\hline Panama & 49.11 \\
\hline Uruguay & 48.97 \\
\hline Argentina & 48.56 \\
\hline Turkey & 47.36 \\
\hline Ecuador & 45.61 \\
\hline Ghana & 45.41 \\
\hline Kenya & 45.49 \\
\hline Paraguay & 45.37 \\
\hline Nigeria & 44.78 \\
\hline Sri Lanka & 43.78 \\
\hline Costa Rica & 42.86 \\
\hline Romania & 41.06 \\
\hline Peru & 40.25 \\
\hline Pakistan & 39.56 \\
\hline Zimbabwe & 39.05 \\
\hline Jamaica & 38.72 \\
\hline Tanzania & 37.83 \\
\hline Bolivia & 36.32 \\
\hline Dominican Republic & 34.12 \\
\hline El Salvador & 28.61 \\
\hline
\end{tabular}


Table D.5. Changes in Government Revenue and Expenditure in Selected Emerging Market Economies: 1980-2000

\begin{tabular}{|c|c|c|c|c|}
\hline & $\begin{array}{l}\text { Change } \\
\text { from } 1980-85 \\
\text { to } 1986-90\end{array}$ & $\begin{array}{l}\text { Change } \\
\text { from 1986-90 } \\
\text { to 1991-95 }\end{array}$ & $\begin{array}{l}\text { Change } \\
\text { from 1990-95 } \\
\text { to } 1996-2000\end{array}$ & $\begin{array}{l}\text { Cumulative change } \\
\text { from } 1980-85 \\
\text { to } 1996-2000\end{array}$ \\
\hline \multicolumn{5}{|c|}{ A. Countries with a history of default } \\
\hline \multicolumn{5}{|l|}{ Argentina } \\
\hline Central government expenditures & n.a. & n.a. & 0.5 & 0.5 \\
\hline Interest payments & -0.5 & 0.3 & 1.2 & 1.1 \\
\hline Central government revenues & -0.2 & 3.1 & 6.7 & 9.7 \\
\hline Tax revenues & 1.2 & 0.4 & 0.9 & 2.5 \\
\hline Trade taxes & 0.4 & -0.7 & -0.1 & -0.4 \\
\hline Central government deficit & n.a. & n.a. & -6.2 & -6.2 \\
\hline Seigniorage revenues & -0.3 & -3.4 & -1.1 & -4.7 \\
\hline \multicolumn{5}{|l|}{ Brazil } \\
\hline Central government expenditures & 9.7 & -0.4 & -6.6 & 2.7 \\
\hline Interest payments & 12.7 & -3.8 & -8.5 & 0.4 \\
\hline Central government revenues & 1.4 & 2.1 & -4.0 & -0.6 \\
\hline Tax revenues & -0.9 & 0.6 & 1.6 & 1.3 \\
\hline Trade taxes & -0.3 & -0.1 & 0.2 & -0.2 \\
\hline Central government deficit & 8.3 & -2.4 & -2.6 & 3.3 \\
\hline Seigniorage revenues & 4.1 & 1.0 & -6.7 & -1.6 \\
\hline \multicolumn{5}{|l|}{ Chile } \\
\hline Central government expenditures & -7.5 & -2.8 & -0.1 & -10.4 \\
\hline Interest payments & 0.9 & -0.6 & -0.8 & -0.6 \\
\hline Central government revenues & -6.3 & -0.9 & -1.3 & -8.5 \\
\hline Tax revenues & -5.1 & 0.5 & -1.2 & -5.7 \\
\hline Trade taxes & 0.3 & -0.1 & -0.5 & -0.3 \\
\hline Central government deficit & -1.2 & -2.0 & 1.2 & -2.0 \\
\hline Seigniorage revenues & 0.4 & -0.1 & -0.7 & -0.3 \\
\hline \multicolumn{5}{|l|}{ Colombia } \\
\hline Central government expenditures & n.a. & n.a. & 4.3 & 4.3 \\
\hline Interest payments & 0.6 & 0.1 & 1.2 & 1.9 \\
\hline Central government revenues & n.a. & n.a. & 1.3 & 1.3 \\
\hline Tax revenues & 1.7 & 1.8 & -0.8 & 2.7 \\
\hline Trade taxes & 0.6 & -1.2 & -0.3 & -0.8 \\
\hline Central government deficit & n.a. & n.a. & 3.0 & 3.0 \\
\hline Seigniorage revenues & 0.5 & -0.5 & -1.3 & -1.3 \\
\hline \multicolumn{5}{|l|}{ Egypt } \\
\hline Central government expenditures & -10.3 & 1.4 & -5.9 & -14.8 \\
\hline Interest payments & 0.6 & 3.6 & -1.3 & 2.9 \\
\hline Central government revenues & -10.7 & 5.2 & -8.2 & -13.7 \\
\hline Tax revenues & -7.2 & 3.2 & -0.8 & -4.8 \\
\hline Trade taxes & -3.4 & -0.4 & 0.0 & -3.9 \\
\hline Central government deficit & 0.4 & -3.8 & 2.3 & -1.1 \\
\hline Seigniorage revenues & -6.1 & 0.0 & -0.9 & -7.1 \\
\hline \multicolumn{5}{|l|}{ Mexico } \\
\hline Central government expenditures & 1.9 & -9.5 & -0.2 & -7.7 \\
\hline Interest payments & 7.9 & -10.5 & -0.8 & -3.4 \\
\hline Central government revenues & 0.4 & -0.6 & -1.5 & -1.7 \\
\hline Tax revenues & 0.1 & -1.1 & -0.6 & -1.6 \\
\hline Trade taxes & 0.0 & 0.2 & -0.4 & -0.2 \\
\hline Central government deficit & 1.5 & -8.9 & 1.3 & -6.1 \\
\hline Seigniorage revenues & -3.8 & -1.2 & 0.2 & -4.7 \\
\hline
\end{tabular}

Source: Authors' calculations based on data from the IMF's Government Finance Statistics and International Financial Statistics 
Table D.5 Cont'd. Changes in Government Revenue and Expenditure in Selected Emerging Market Economies: 1980-2000

\begin{tabular}{|c|c|c|c|c|}
\hline & $\begin{array}{l}\text { Change } \\
\text { from } 1980-85 \\
\text { to } 1986-90\end{array}$ & $\begin{array}{l}\text { Change } \\
\text { from } 1986-90 \\
\text { to } 1991-95\end{array}$ & $\begin{array}{c}\text { Change } \\
\text { from } 1990-95 \\
\text { to } 1996-2000\end{array}$ & $\begin{array}{l}\text { Cumulative change } \\
\text { from } 1980-85 \\
\text { to } 1996-2000\end{array}$ \\
\hline \multicolumn{5}{|c|}{ A. Countries with a history of default (cont.) } \\
\hline \multicolumn{5}{|l|}{ Philippines } \\
\hline Central government expenditures & 4.4 & 2.1 & 0.5 & 6.9 \\
\hline Interest payments & 3.9 & -0.3 & -1.5 & 2.2 \\
\hline Central government revenues & 2.7 & 3.4 & -0.9 & 5.1 \\
\hline Tax revenues & 1.5 & 3.2 & 0.0 & 4.7 \\
\hline Trade taxes & 0.3 & 1.6 & -1.5 & 0.4 \\
\hline Central government deficit & 1.7 & -1.3 & 1.4 & 1.8 \\
\hline Seigniorage revenues & -1.7 & 0.4 & -0.3 & -1.7 \\
\hline \multicolumn{5}{|l|}{ Turkey } \\
\hline Central government expenditures & n.a. & 5.1 & 10.9 & 15.9 \\
\hline Interest payments & n.a. & 0.4 & 7.4 & 7.9 \\
\hline Central government revenues & n.a. & 3.2 & 6.5 & 9.7 \\
\hline Tax revenues & n.a. & 1.9 & 6.0 & 7.9 \\
\hline Trade taxes & n.a. & -0.2 & -0.3 & -0.5 \\
\hline Central government deficit & n.a. & 1.9 & 4.3 & 6.3 \\
\hline Seigniorage revenues & 0.4 & -0.4 & 0.3 & 0.4 \\
\hline \multicolumn{5}{|l|}{ Venezuela } \\
\hline Central government expenditures & -4.2 & -1.1 & 0.6 & -4.6 \\
\hline Interest payments & 1.0 & 0.8 & -1.1 & 0.7 \\
\hline Central government revenues & -7.8 & -1.8 & 1.1 & -8.5 \\
\hline Tax revenues & -7.4 & -1.4 & -0.4 & -9.1 \\
\hline Trade taxes & -0.6 & -0.8 & -0.2 & -1.6 \\
\hline Central government deficit & 3.6 & 0.6 & -0.5 & 3.8 \\
\hline Seigniorage revenues & -0.3 & 1.1 & -0.2 & 0.5 \\
\hline \multicolumn{5}{|c|}{ B. Countries with no history of default } \\
\hline \multicolumn{5}{|l|}{ India } \\
\hline Central government expenditures & 2.8 & -1.4 & -0.2 & 1.2 \\
\hline Interest payments & 1.1 & 0.7 & 0.3 & 2.2 \\
\hline Central government revenues & 1.1 & -0.9 & -0.5 & -0.3 \\
\hline Tax revenues & 0.6 & -1.3 & -0.5 & -1.1 \\
\hline Trade taxes & 0.9 & -0.9 & -0.4 & -0.4 \\
\hline Central government deficit & 1.7 & -0.5 & 0.4 & 1.5 \\
\hline Seigniorage revenues & 0.3 & 0.0 & -0.8 & -0.4 \\
\hline \multicolumn{5}{|l|}{ Korea } \\
\hline Central government expenditures & -1.5 & 0.9 & 0.9 & 0.3 \\
\hline Interest payments & -0.3 & -0.3 & -0.1 & -0.7 \\
\hline Central government revenues & -0.6 & 1.0 & 2.0 & 2.4 \\
\hline Tax revenues & -0.5 & -0.1 & 0.7 & 0.0 \\
\hline Trade taxes & -0.2 & -1.1 & 0.0 & -1.3 \\
\hline Central government deficit & -0.9 & -0.1 & -1.1 & -2.0 \\
\hline Seigniorage revenues & 1.3 & -0.4 & -1.2 & -0.3 \\
\hline \multicolumn{5}{|l|}{ Malaysia } \\
\hline Central government expenditures & -6.8 & -5.4 & -2.8 & -15.0 \\
\hline Interest payments & 2.2 & -2.6 & -1.7 & -2.1 \\
\hline Central government revenues & -2.3 & 0.3 & -3.3 & -5.2 \\
\hline Tax revenues & -4.0 & 1.7 & -0.8 & -3.1 \\
\hline Trade taxes & -2.4 & -0.7 & -0.9 & -4.0 \\
\hline Central government deficit & -4.6 & -5.7 & 0.5 & -9.8 \\
\hline Seigniorage revenues & 0.5 & 1.8 & -0.8 & 1.6 \\
\hline \multicolumn{5}{|l|}{ Singapore } \\
\hline Central government expenditures & 2.6 & -7.7 & 2.2 & -2.9 \\
\hline Interest payments & 0.6 & -2.2 & -1.2 & -2.8 \\
\hline Central government revenues & 3.1 & 0.4 & 6.3 & 9.8 \\
\hline Tax revenues & -3.6 & 2.1 & -1.2 & -2.8 \\
\hline Trade taxes & -0.7 & -0.3 & -0.1 & -1.1 \\
\hline Central government deficit & -0.4 & -8.2 & -4.0 & -12.7 \\
\hline Seigniorage revenues & 0.0 & -0.3 & -1.0 & -1.3 \\
\hline \multicolumn{5}{|l|}{ Thailand } \\
\hline Central government expenditures & -3.0 & 0.2 & 2.4 & -0.3 \\
\hline Interest payments & 0.4 & -1.7 & -0.3 & -1.6 \\
\hline Central government revenues & 1.9 & 1.7 & -1.9 & 1.7 \\
\hline Tax revenues & 1.6 & 1.7 & -1.5 & 1.7 \\
\hline Trade taxes & 0.2 & -0.3 & -1.3 & -1.4 \\
\hline Central government deficit & -4.9 & -1.5 & 4.3 & -2.1 \\
\hline Seigniorage revenues & 0.5 & 0.1 & -0.1 & 0.5 \\
\hline
\end{tabular}




\section{REFERENCES}

Beim, David O., and Charles W. Calomiris. 2001. Emerging Financial Markets. New York: McGraw-Hill/Irwin.

Bosher, J.F. 1970. French Finances 1770-1795; from business to bureaucracy. Cambridge: Cambridge University Press.

Bouchard, Leon.1891. System financier de l'ancien regime, Paris: Guillaumin.

Bulow, Jeremy, and Kenneth Rogoff, 1989. "Sovereign Debt: Is to Forgive to Forget?" American Economic Review 79 (March) , 43-50.

Bulow, Jeremy, and Kenneth Rogoff. 1990. "Cleaning Up Third-World Debt Without Getting Taken To the Cleaners.” Journal of Economic Perspectives, vol. 4 (Winter): pp. 31-42.

Cline, William. 1995. International Debt Reexamined. Washington: Institute for International Economics.

Díaz-Alejandro, Carlos. 1983. "Stories of the 1930s for the 1980s." In P. Aspe, et al. (eds.) Financial Policies and the World Capital Market: The Problem of Latin American Countries, Chicago: The University of Chicago Press for the NBER

Díaz-Alejandro, Carlos. 1984, “Latin American Debt: I Don’t Think We Are in Kansas Anymore," Brookings Papers on Economic Activity, No.2, pp. 335-403.

Easterly, William R. 1989. "Fiscal Adjustment and Deficit Financing During the Debt Crisis." In I. Husain and I. Diwan, eds., Dealing with the Debt Crisis. Washington DC: The World Bank: 91-113.

Easterly, William and Klaus Schmidt-Hebbel, 1994. "Fiscal Adjustment and Macroeconomic Performance." In W. Easterly et al. (eds.) Public Sector Deficits and Macroeconomic Performance. Oxford University Press for the World Bank.

Easterly, William R. 2001. The Elusive Quest for Growth. MIT Press: Cambridge, MA.

Eichengreen, Barry, Ricardo Hausmann, and Ugo Panizza. 2002. "Original Sin: The Pain, the Mystery, and the Road to Redemption." Mimeograph. University of California, Berkeley.

Giovannini, Alberto and Martha de Melo. 1993. "Government Revenue from Financial Repression." American Economic Review, vol. 83 (No. 4): 953-963.

Goldstein, Morris. 2003. "Debt Sustainability, Brazil, and the IMF." Working Paper WP03-1. Institute for International Economics. 
International Monetary Fund. 1995. Private Market Financing for Developing Countries. Washington, DC: International Monetary Fund.

International Monetary Fund. 2002. "Assessing Sustainability," available at: http://www.imf.org/external/np/pdr/sus/2002/eng/052802.htm

International Monetary Fund. 2003. World Economic Outlook. (April) Washington, DC: International Monetary Fund.

Jahjah, Samir, and Peter Montiel. 2003. "Exchange Rate Policy and Debt Crises in Emerging Economies”. IMF Working Paper WP/03/60. March.

Kaminsky, Graciela L., Carmen M. Reinhart, and Carlos A. Végh. 2003. "When It Rains, It Pours: Procyclical Capital Flows and Policies.” Mimeograph.

McKinnon, Ronald.1991. The Order of Economic Liberalization. Baltimore: Johns Hopkins University Press.

Morris, Stephen, and Hyun Song Shin. 2001. "Coordination Risk and the Price of Debt." (Forthcoming, European Economic Review).

Obstfeld, Maurice. 1994. "The Logic of Currency Crises.” Cahiers Economiques et Monetaires, 43.

Obstfeld, Maurice, and Kenneth S. Rogoff. 1996. Foundations of International Macroeconomics. Cambridge: MIT Press.

Prasad, Eswar, Kenneth Rogoff, Shang-Jin Wei and Ayhan Kose. 2003. "Effects of Financial Globalization on Developing Countries: Some Empirical Evidence,” IMF Occasional Paper. (Forthcoming).

Reinhart, Carmen M. 2002. "Default, Currency Crisis and Sovereign Credit Ratings." World Bank Economic Review, vol. 16 (no. 2): 151-170.

Reinhart, Carmen M. and Vincent R. Reinhart. 2003. "The Twin Fallacies About Exchange Rate Policy in Emerging Markets.," NBER Working Paper 9670. April.

Reinhart, Carmen M. and Kenneth S. Rogoff. 2002. "The Modern History of Exchange Rate Arrangements a Reinterpretation.” NBER Working Paper 8963. May.

Reinhart, Carmen M., Kenneth S. Rogoff, and Miguel A. Savastano. 2003. "Addicted to Dollars." Mimeograph, IMF. 
Reissen, Helmut. 1989. "Public Debt: North and South.” In I. Husain and I. Diwan, eds., Dealing with the Debt Crisis. Washington DC: The World Bank: 116-126.

Rogoff, Kenneth S. 1999. "International Institutions for Reducing Global Financial Instability." Journal of Economic Perspectives, vol. 13 (no. 4): 21-42.

Sims, Christopher, 2001. "Fiscal Consequences for Mexico of Adopting the Dollar," Journal of Money, Credit, and Banking Vol. 33, No. 2, Part 2: 597-616

Velasco, Andres. 1996. "Fixed Exchange Rates: Credibility, Flexibility and Multiplicity." European Economic Review 40: 1023-1035.

Vives, Jaime V. 1969. An Economic History of Spain. Princeton, N.J.: Princeton University Press

Williamson, John. 1988. Voluntary Approaches to Debt Relief, Policy Analysis in International Economics 25, Washington: Institute for International Economics.

Williamson, John. 2002. “Is Brazil Next?” International Economics Policy Briefs PB 02-7, Washington: Institute for International Economics.

Winkler, Max. 1933. Foreign Bonds: An Autopsy. Philadelphia: R. Swain

Wynne, William. 1951. State Insolvency and Foreign Bondholders Vol.2 New Haven, Conn.: Yale University Press 